\title{
Nearshore Sediment Thickness, Fire Island, New York
}

Stanley D. Locker, Jennifer L. Miselis, Noreen A. Buster, Cheryl J. Hapke, Heidi M. Wadman, Jesse E. McNinch, Arnell S. Forde, and Chelsea A. Stalk

Open-File Report 2017-1024

U.S. Department of the Interior

U.S. Geological Survey 


\section{U.S. Department of the Interior \\ RYAN ZINKE, Secretary}

\section{U.S. Geological Survey \\ William W. Werkheiser, Acting Director}

U.S. Geological Survey, Reston, Virginia: 2017

For more information on the USGS—-the Federal source for science about the Earth, its natural and living resources, natural hazards, and the environment-visit https://www.usgs.gov/ or call 1-888-ASK-USGS (1-888-275-8747).

For an overview of USGS information products, including maps, imagery, and publications, visit https://store.usgs.gov/.

Any use of trade, firm, or product names is for descriptive purposes only and does not imply endorsement by the U.S. Government.

Although this information product, for the most part, is in the public domain, it also may contain copyrighted materials as noted in the text. Permission to reproduce copyrighted items must be secured from the copyright owner.

Suggested citation:

Locker, S.D., Miselis, J.L., Buster, N.A., Hapke, C.J., Wadman, H.M., McNinch, J.E., Forde, A.S., and Stalk, C.A., 2017, Nearshore sediment thickness, Fire Island, New York: U.S. Geological Survey Open-File Report 2017-1024, 21 p., https://doi.org/10.3133/ofr20171024. 


\section{Acknowledgments}

Funding was provided through Hurricane Sandy Supplemental Project GS2-2B. The authors would like to acknowledge the cooperation and logistical support of the National Park Service at Fire Island National Seashore. We thank Jason Pipes and Nick Spore of the U.S. Army Corps of Engineers for their assistance at sea. We also thank Laura Brothers and Wayne Baldwin of the U.S. Geological Survey for their thoughtful reviews. 


\section{Contents}

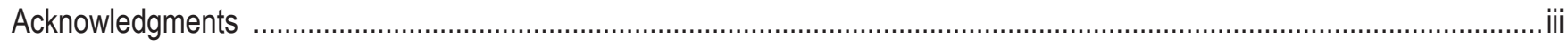

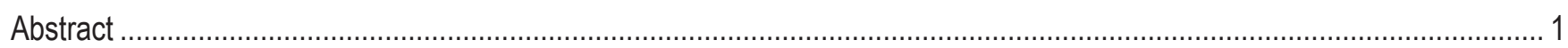

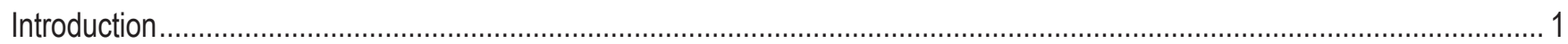

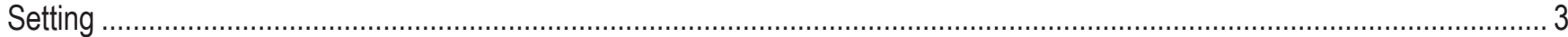

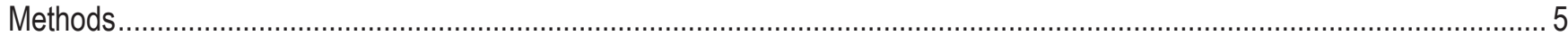

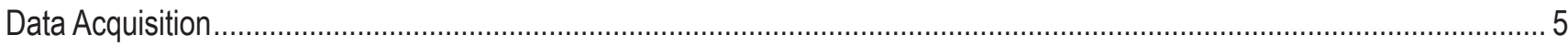

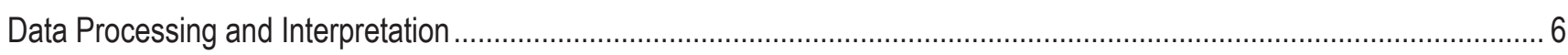

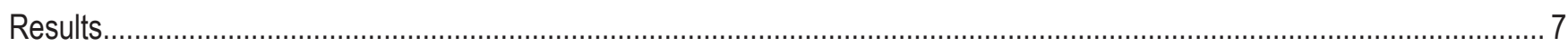

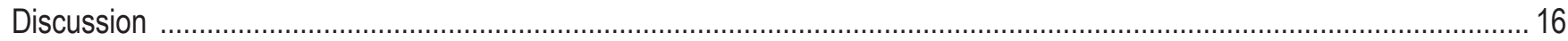

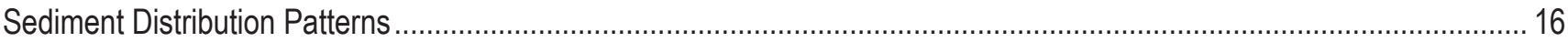

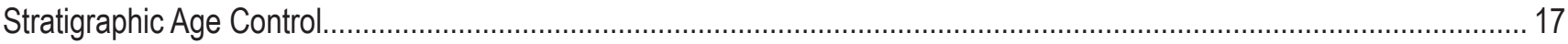

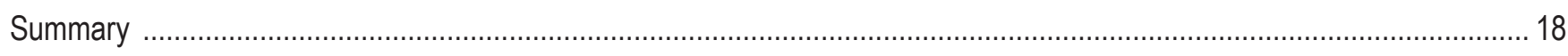

Selected References. 


\section{Figures}

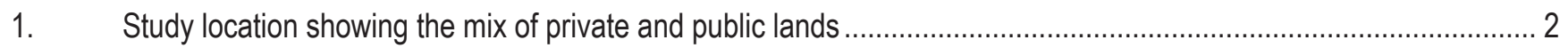

2. Location of chirp 512i profiles shown in figures $8-15$ and 20 on sidescan sonar backscatter ................................. 4

3. Locations of chirp 512i profiles shown in figures $8-15$ and 20 overlain on bathymetry from Denny and others......... 4

4. The U.S. Army Corps of Engineers' Lighter Amphibious Resupply Cargo survey vessel towed an Edgetech chirp 512i subbottom profiler mounted on a catamaran sled ...

5. Trackline coverage of chirp subbottom data collected in 2014 by the U.S. Army Corps of Engineers and selected U.S. Geological Survey trackline coverage from 2011 and 2014 used to guide horizon correlations for this study..... 6

6. National Oceanic and Atmospheric Administration (NOAA) tide zones referenced to Sandy Hook tide station with associated corrector values

8. Chirp profile 8 from the eastern end of the study area showing relatively thin Holocene section ............................. 8

9. Chirp profile 15 from the eastern zone illustrating the thin shoreface sediment in this area.................................... 9

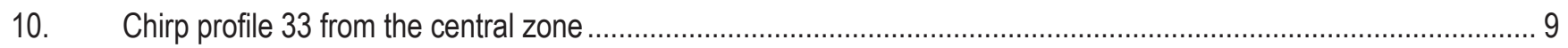

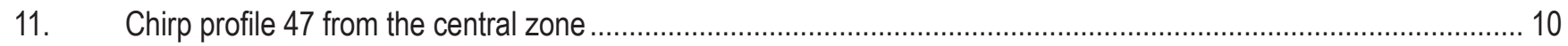

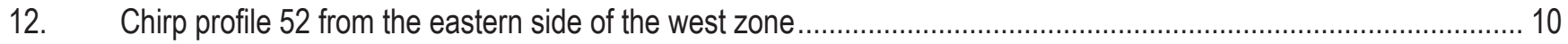

13. Chirp profile 63 from the western end of the study showing the wedge of T1 sediment between R1 and R2: .........11

14. Alongshore chirp profile from a previous survey carried out by the U.S. Geological Survey in the central and western zone showing the bifurcation of R0 to R1 and R2 crossing the western margin of the Pleistocene outwash lobe......

15. Alongshore chirp profile in about 6 meters of water illustrates the complex sedimentary units that comprise the T1 section in the central zone.....

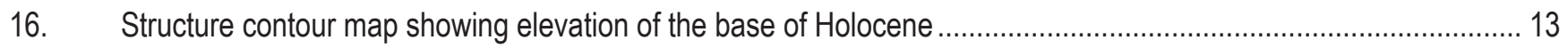

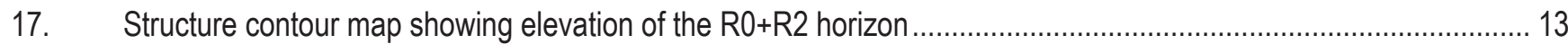

18. Map of Holocene sediment thickness illustrates the influence of shoreface-attached sand ridges and landward

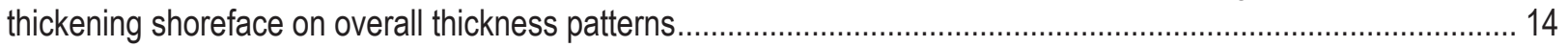

19. The T2 isopach map illustrates an overall thinning section from west to east ................................................. 14

20. Chirp profile from the eastern zone that crosses the wilderness breach ebb-tidal delta, running parallel to shore ... 15 


\section{Conversion Factors}

International System of Units to U.S. customary units

\begin{tabular}{|c|c|c|}
\hline Multiply & By & To obtain \\
\hline \multicolumn{3}{|c|}{ Length } \\
\hline meter $(\mathrm{m})$ & 3.281 & foot $(\mathrm{ft})$ \\
\hline meter $(\mathrm{m})$ & 1.094 & yard (yd) \\
\hline kilometer $(\mathrm{km})$ & 0.621 & mile $(\mathrm{mi})$ \\
\hline kilometer $(\mathrm{km})$ & 0.540 & mile, nautical (nmi) \\
\hline \multicolumn{3}{|c|}{ Time } \\
\hline millisecond (ms) & 0.001 & seconds (s) \\
\hline \multicolumn{3}{|c|}{ Velocity } \\
\hline meters per second $(\mathrm{m} / \mathrm{s})$ & 3.281 & feet per second $(\mathrm{ft} / \mathrm{s})$ \\
\hline kilometers per hour $(\mathrm{km} / \mathrm{hr})$ & 0.621 & miles per hour (mi/hr) \\
\hline
\end{tabular}

\section{Datum}

Data were acquired in the geographic coordinate system World Geodetic System of 1984 (WGS84) and were transformed to the projected coordinate system North American Datum of 1983 (NAD83), Universal Transverse Mercator (UTM) zone 18N.

\section{Abbreviations}

$\begin{array}{ll}\text { DN } & \text { Digital Number } \\ \text { DOI } & \text { Department of the Interior } \\ \text { GMT } & \text { Greenwich Mean Time } \\ \text { GPS } & \text { Global Positioning System } \\ \text { KHz } & \text { Kilohertz } \\ \text { LARC } & \text { Lighter Amphibious Resupply Cargo } \\ \text { Mins. } & \text { Minutes } \\ \text { MLLW } & \text { Mean lower low water } \\ \text { MHW } & \text { Mean High Water } \\ \text { NAD } & \text { North American Datum } \\ \text { NAVD 88 } & \text { North American Vertical Datum of 1988 } \\ \text { NOAA } & \text { National Oceanic and Atmospheric Administration } \\ \text { NW } & \text { Northwest } \\ \text { NWR } & \text { National Wildlife Refuge } \\ \text { RTK } & \text { Real-Time Kinematic } \\ \text { SE } & \text { Southeast } \\ \text { USACE } & \text { U.S. Army Corps of Engineers } \\ \text { USGS } & \text { U.S. Geological Survey } \\ \text { UTM } & \text { Universal Transverse Mercator } \\ \text { WHCMSC } & \text { Woods Hole Coastal and Marine Science Center } \\ \text { WGS } & \text { World Geodetic System }\end{array}$




\section{Nearshore Sediment Thickness, Fire Island, New York}

Stanley D. Locker, ${ }^{1}$ Jennifer L. Miselis, ${ }^{1}$ Noreen A. Buster, ${ }^{1}$ Cheryl J. Hapke,,${ }^{1}$ Heidi M. Wadman, ${ }^{2}$ Jesse E. McNinch, ${ }^{2}$ Arnell S. Forde, ${ }^{1}$ and Chelsea A. Stalk ${ }^{3}$

\section{Abstract}

Investigations of coastal change at Fire Island, New York (N.Y.), sought to characterize sediment budgets and determine geologic framework controls on coastal processes. Nearshore sediment thickness is critical for assessing coastal system sediment availability, but it is largely unquantified due to the difficulty of conducting geological or geophysical surveys across the nearshore. This study used an amphibious vessel to acquire chirp subbottom profiles. These profiles were used to characterize nearshore geology and provide an assessment of nearshore sediment volume. Two resulting sediment-thickness maps are provided: total Holocene sediment thickness and the thickness of the active shoreface. The Holocene sediment section represents deposition above the maximum flooding surface that is related to the most recent marine transgression. The active shoreface section is the uppermost Holocene sediment, which is interpreted to represent the portion of the shoreface thought to contribute to present and future coastal behavior. The sediment distribution patterns correspond to previously defined zones of erosion, accretion, and stability along the island, demonstrating the importance of sediment availability in the coastal response to storms and seasonal variability. The eastern zone has a thin nearshore sediment thickness, except for an ebb-tidal deposit at the wilderness breach caused by Hurricane Sandy. Thicker sediment is found along a central zone that includes shoreface-attached sand ridges, which is consistent with a stable or accretional coastline in this area. The thickest overall Holocene section is found in the western zone of the study, where a thicker lower section of Holocene sediment appears related to the westward migration of Fire Island Inlet over several hundred years.

\section{Introduction}

Fire Island, N.Y., is a narrow, sandy, barrier island (fig. 1) in a high-energy wave and wind environment that exhibits spatially varying patterns of shoreline change: net erosion in the eastern region, stability in the central region, and accretion in the west (Hapke and others, 2010; Lentz and others, 2013; Schwab and others, 2013; Hapke and others, 2016). Communities on the island periodically turn to beach nourishment to reduce erosion rates along sections that experience erosion (Lentz and others, 2013). Efforts to better understand coastal erosion patterns included analyzing beach profiles to assess subaerial sediment budgets (Hapke and others, 2013; Nelson and Hapke, 2015), calculating alongshore sediment transport rates to identify convergences (supply) and divergences (loss) within the littoral system (Kana, 1995; Hapke and others, 2010), assessing drivers and patterns of coastal geomorphic change (Lentz and Hapke, 2011; Kratzmann and Hapke, 2012; Lentz and others, 2013), and documenting the inner-shelf geologic framework control on sediment-transport patterns (Schwab and others, 2013, 2014a; Warner and others, 2014). While cross-shore beach profile transects are commonly used to determine volume changes across the upper shoreface to the "depth of closure" (Hallermeier, 1981; Kana and others, 2011), these methods do not measure the total volume of shoreface sediment that exists in the

\footnotetext{
${ }^{1}$ U.S. Geological Survey, St. Petersburg Coastal and Marine Science Center, 600 4th Street South, St. Petersburg, FL 33701

${ }^{2}$ U.S. Army Corps of Engineers, Engineering Research and Development Center, Coastal Hydraulics Laboratory, Field Research Facility, 1261 Duck Rd., Kitty Hawk, NC 27949

${ }^{3}$ Cherokee Nation Technologies, 600 4th Street South, St. Petersburg, FL 33701
} 


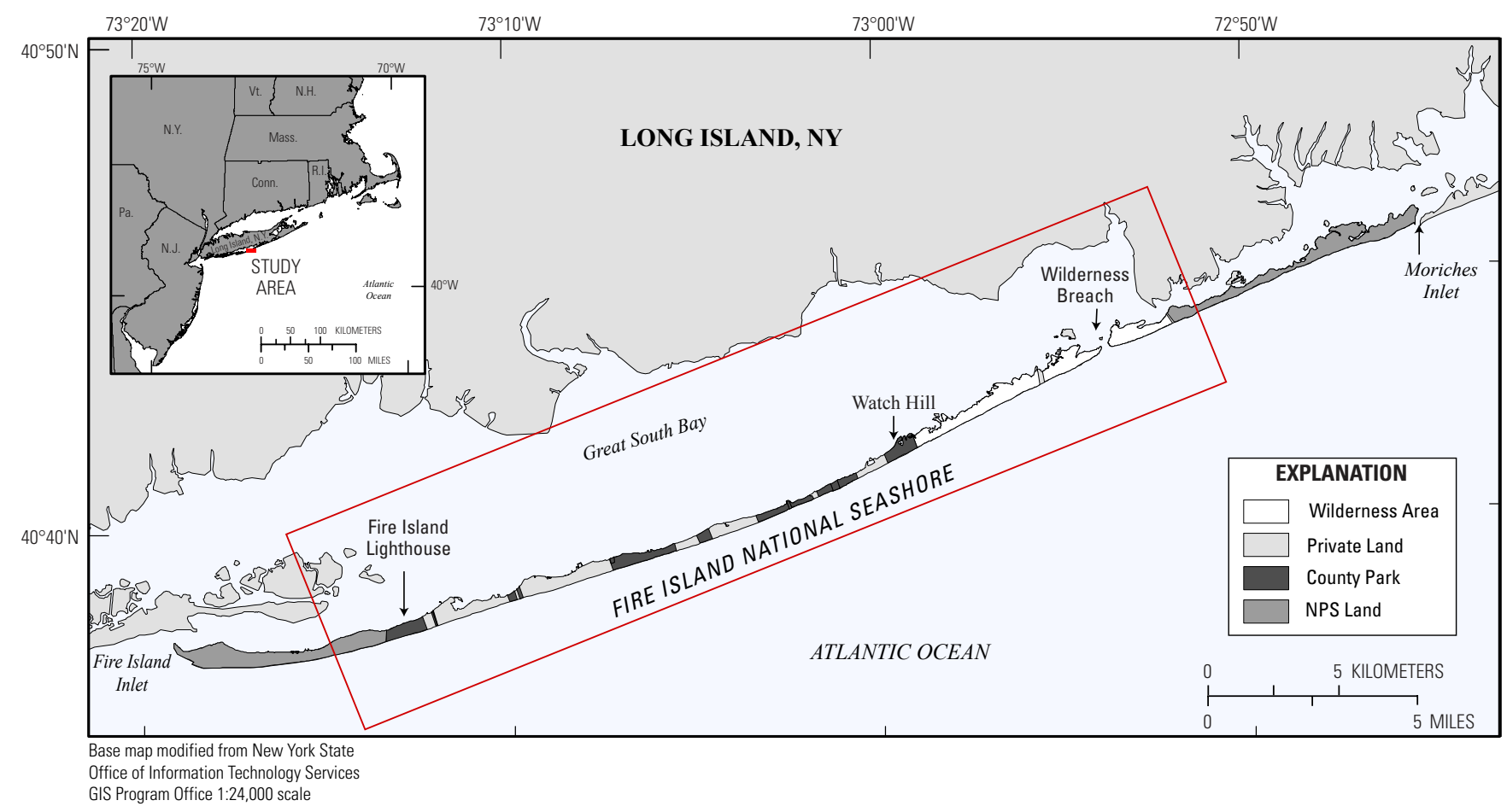

Figure 1. Study location showing the mix of private and public lands.

nearshore. Nearshore sediment volume is highly mobile on short timescales and is linked to decadal patterns of shoreline erosion (Miselis and McNinch, 2006), whereas studies show that inner-shelf sediment volume controls longer-term coastline behavior (Schwab and others, 2014a; Warner and others, 2014), making coastal sediment availability relevant to management concerns over a range of timescales.

Hurricane Sandy made landfall as a post-tropical cyclone near Brigantine, New Jersey (N.J.), on October 29, 2012, with 130-kilometer-per-hour maximum sustained winds that affected most of the U.S. Atlantic coastline (Blake and others, 2013). After the storm, Department of the Interior (DOI) agencies mobilized to study how the storm affected coastal systems throughout the Eastern and Northeastern United States, including Fire Island. Changes to Fire Island included significant decreases in dune heights, overwash on the eastern part of the island, a loss of infrastructure within local communities, and the creation of a wilderness breach (fig 1 ) (Hapke and others, 2013; Sopkin and others, 2014; Nelson and others, 2016). The U.S. Geological Survey (USGS) has a history of characterizing storm responses and predicting storm impacts, but little data exists on the nature of post-storm recoveries. To that end, the USGS directed Hurricane Sandy Supplemental Funding be used to examine beach recovery at Fire Island. Because of established linkages between sediment availability and coastal evolution processes (Schwab and others, 2014a; Warner and others, 2014; Hapke and others, 2016), one objective of the project was to identify relationships between beach recovery and sediment availability.

Magnitudes of alongshore and cross-shore transport, and the total volume of sediment available to be transported, are key factors for understanding island response to, and recovery from, storms. These factors are also essential for improving predictions of coastal behavior in response to increased rates of sea-level rise. Studies of the inner-shelf geologic framework at Fire Island show the importance of shoreface-attached sand ridges as a landward supply route for sand over long time scales (Schwab and others, 2014a). Previous studies at Fire Island only conducted geophysical surveys to map sediment volumes in the lower portion of the active shoreface onto the inner shelf, omitting the nearshore zone 
between the lower shoreface and the shoreline. This lack of data coverage is common because shallow water depths and wave breaking in the nearshore represent significant challenges to boat access and the acquisition of acoustic geophysical data. Because nearshore sediment shifts dynamically in response to storms and seasonal patterns of wind and wave energy, quantifying this volume of sediment is critical for characterizing interannual- to decadal-scale coastal sediment budgets.

The objective of this study is to characterize spatial variations in nearshore sediment thickness up to the shoreline at Fire Island, which could contribute to beach recovery or indicate vulnerabilities to future storms. Filling in the geophysical data gap between the shoreline and the landward limit of existing inner-shelf data (Denny and others 2015b; Schwab and others, 2014b, 2016) required use of an amphibious vehicle operated by the United States Army Corps of Engineers (USACE, http://www.frf. usace.army.mil/larc/larcsystem.shtml). Obtaining this information is critical for (1) defining the volume of sediment available offshore after major storms, (2) providing information about the history of sediment exchange between the island (subaerial) and the lower shoreface (subaqueous), and (3) identifying geologic features that could contribute to variability in beach-profile and shoreline change.

\section{Setting}

Fire Island, one of several barrier islands along the south shore of Long Island, N.Y., is a sandy barrier island approximately 50 kilometers $(\mathrm{km})$ long, extending from Fire Island Inlet at its westernmost point to Moriches Inlet at its easternmost point (fig. 1). The numerous stakeholders on the island include the Fire Island National Seashore, private communities, a wilderness area, and county and State parks. The geology of Long Island, N.Y., is dominated by terminal moraines and glacial outwash deposits derived from Wisconsinan Laurentide glacial advance and retreat, accompanied by Holocene sealevel transgression, which eroded and redistributed outwash deposits to form the present barrier-island system (Leatherman, 1985; Stone and Borns, 1986; see discussion in Schwab and others, 2014a). Alongshore changes in island width, varying from 0.5 to $1.0 \mathrm{~km}$, are related to a history of the inlet opening and closing, overwash processes, and aeolian dune building, all of which contributed to the geomorphology of the island (Leatherman, 1985). Previous studies showed the coastline retreating landward at the eastern end, stable or accretional in the central portion of the island, and stable but migrating westward at the western end (Leatherman, 1985; Kana, 1995; Hapke and others, 2010, 2016).

The tidal range at Fire Island is $1-1.3 \mathrm{~m}$ (Leatherman, 1985), and the mean significant wave height is $1.3 \mathrm{~m}$ (Wilson and others, 2015). Prevailing westerly winds range from the northwest to the southwest. Stronger, storm-driven winds and currents flow from the east and lead to a net westwarddirected alongshore sediment transport over periods of decades or more (Leatherman, 1985). This net westward alongshore sediment transport led to progradation of the western end of the island by approximately $8 \mathrm{~km}$ between 1825 and 1940, until jetty construction and periodic dredging stabilized the location of Fire Island Inlet at Democrat Point (Saville, 1960; Leatherman, 1985).

Previous investigations of the framework geology in the area demonstrated the importance of inner-shelf, shoreface-attached sand ridges (figs. 2 and 3) that contribute sediment to the shoreface through erosion of the glacial outwash sands and gravels exposed by ravinement processes (Schwab and others, 2000, 2013, 2014a, b). The location of the shoreface-attached sand ridges is correlated with areas of island stability in the central and western portion of Fire Island. At the eastern end of Fire Island, where shoreface-attached sand ridges are absent, the shoreline exhibits net erosion and landward retreat (Hapke and others, 2010; Schwab and others, 2013). Repeated seafloor mapping and modeling of flow patterns and sediment transport on the inner-shelf sand ridges show that while the short-term mixed current flow directions drive both offshore and onshore sediment transport, the dominance of strong winds 


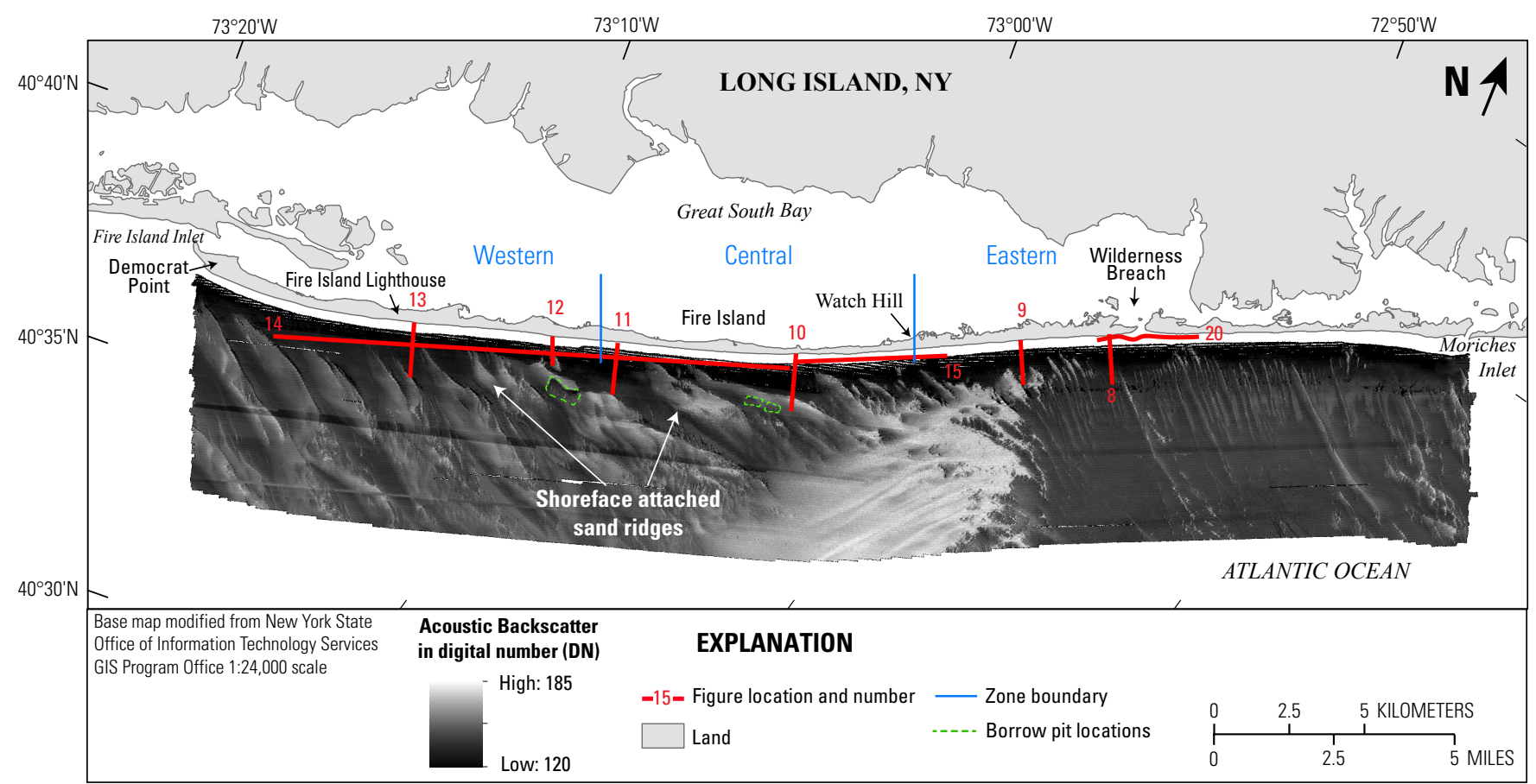

Figure 2. Location of chirp 512i profiles (red) shown in figures 8-15 and 20 on sidescan sonar backscatter from Schwab and others (2013).

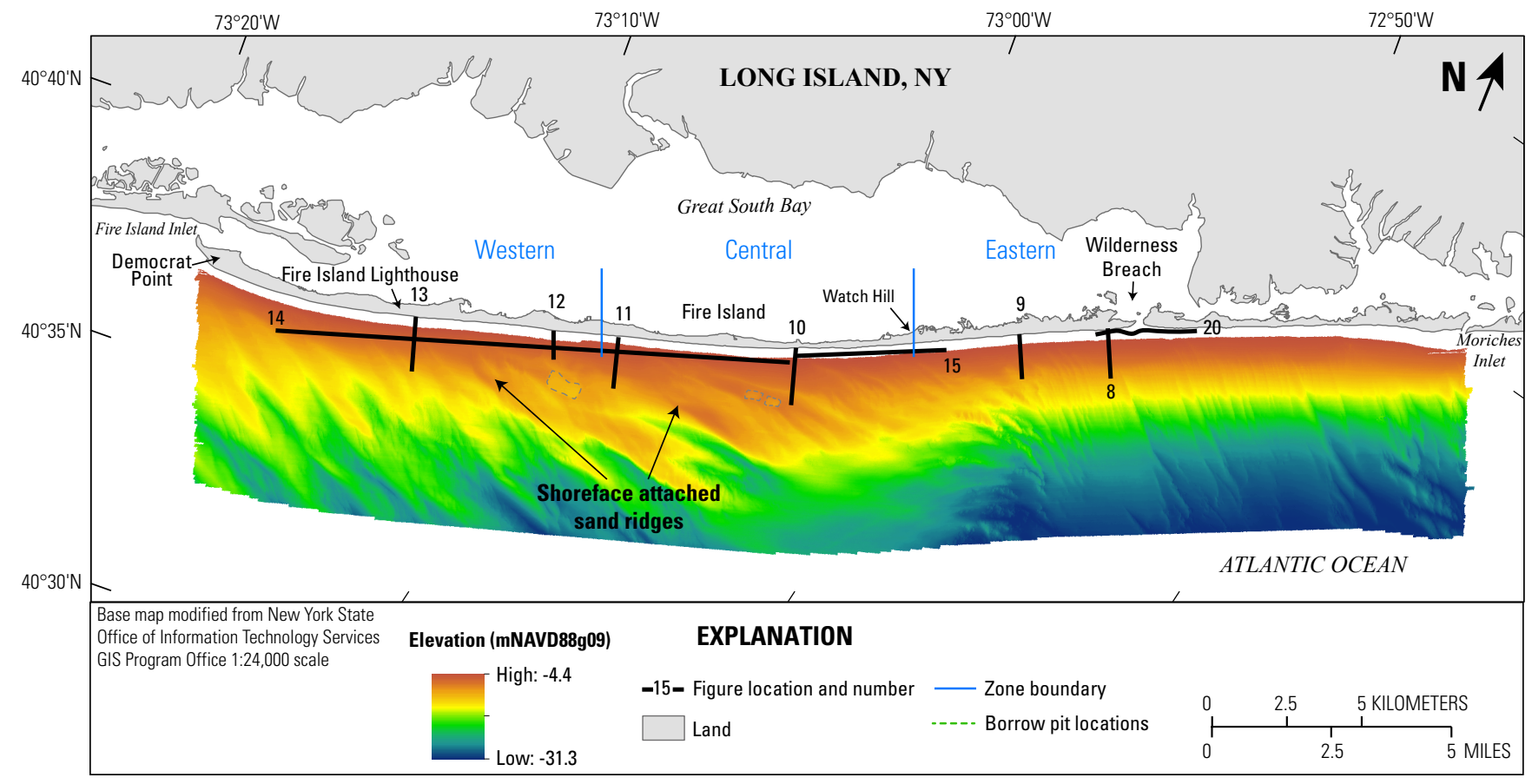

Figure 3. Locations of chirp 512i profiles (black) shown in figures 8-15 and 20 overlain on bathymetry from Denny and others (2015a). Elevation is expressed in meters $(\mathrm{m})$. 
and current flow from the east result in a net western migration of the sand ridges and a shoreward flux of sediment in troughs between sand ridges (Schwab and others, 2014a; Warner and others, 2014).

\section{Methods}

\section{Data Acquisition}

Subbottom profiles were collected between 14 and 23 June, 2014, and between 10 and 12 July, 2014, by the USACE through a cooperative agreement with the USGS. To maximize shallow-water coverage, high-resolution seismic reflection data were collected from the USACE Lighter Amphibious Resupply Cargo (LARC) vehicle (fig. 4). An Edgetech chirp 512i subbottom profiler was towed from the starboard side of the LARC in a catamaran sled so that the transducers were $\sim 0.91 \mathrm{~m}$ below the water's surface (fig. 4). The vessel and towing configuration allowed seismic data to be collected in $<0.5 \mathrm{~m}$ water depth and up the lower beach face. A pulse with a width of $0.7-12$ kilohertz $(\mathrm{kHz})$ and a length of 20 milliseconds (ms) was used to penetrate shoreface sands while maintaining vertical resolution. Real-Time Kinematic-Global Positioning System (RTK-GPS) data were input to Hypack 2014 for navigation (see Nelson and others, 2016, for information on GPS configuration). Hypack 2014 was also used to pass-through position data to the chirp acquisition system.

The survey was conducted along 225 line-kilometers $(\mathrm{km})$ of the nearshore (fig. 5) and was designed for coverage across three geomorphic zones (west, central, and east), as identified in previous reports (Hapke and others, 2013; Schwab and others, 2013), rather than for dense coverage in a smaller area. The survey included 18 shore-perpendicular lines with an average spacing of 2-2.5 km that extended $\sim 2 \mathrm{~km}$ offshore to overlap with data previously collected from the inner shelf by the USGS (Denny and others, 2015b; Schwab and others 2016). The longer shore-perpendicular track lines were connected by 17 shore-oblique lines, $\sim 2.5 \mathrm{~km}$-long, to minimize transit time. To focus coverage in the unmapped area of the nearshore, 22 shorter, 1-km-long dip lines were surveyed between the longer lines. Finally, three shore-parallel lines were surveyed, approximating the 4-, 10-, and 15-m isobaths, although survey conditions prevented the completion of the 4-m line in the east of the study area.

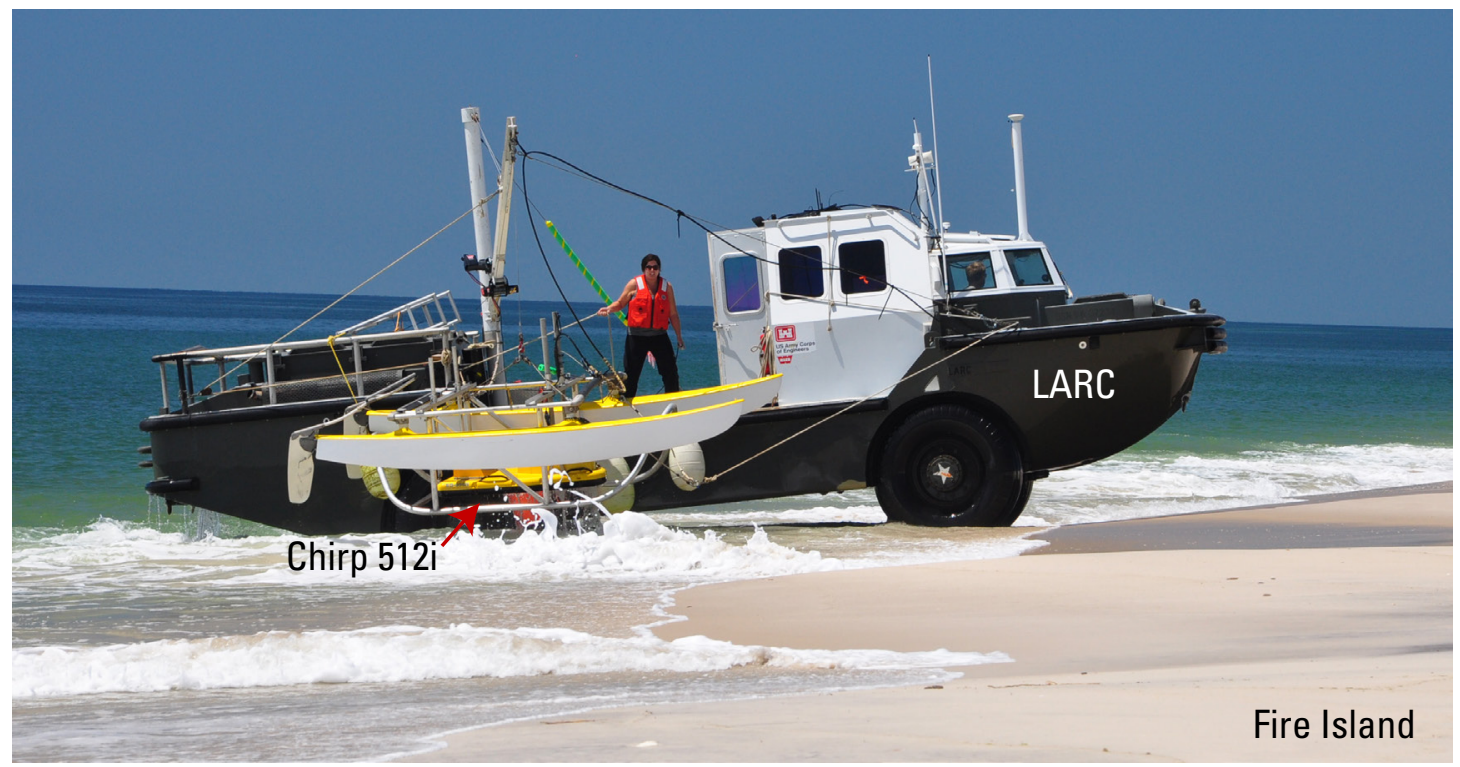

Figure 4. The U.S. Army Corps of Engineers' Lighter Amphibious Resupply Cargo (LARC) survey vessel towed an Edgetech chirp 512i subbottom profiler mounted on a catamaran sled. (Photograph credit: C. Hapke.) 


\section{Data Processing and Interpretation}

The chirp data were processed and interpreted using Chesapeake Technology SonarWiz v. 6 software. The processing in SonarWiz included swell filtering, gain adjustments, and GPS antenna layback/offset corrections. A selection of 512i chirp profiles collected in 2011 and 2014 by the USGS Woods Hole Coastal and Marine Science Center (WHCMSC) (Denny and others, 2015b; Schwab and others, 2016) were added to the dataset to aid with reflector correlation (fig. 5), but only the data from the 2014 USACE-USGS surveys were used for maps in this study. The depth to digitized reflectors and the seafloor $(x, y, z$ data) were exported in milliseconds travel time from SonarWiz at 2-second along-track time intervals. Travel time in milliseconds was converted to meters $(\mathrm{m})$ using sound velocities of 1,500 meters/second $(\mathrm{m} / \mathrm{s})$ for water and $1,650 \mathrm{~m} / \mathrm{s}$ for sediment, corrected for transducer tow depth $(0.91 \mathrm{~m})$ and then corrected for tides referenced to mean lower low water (MLLW). A tidal adjustment was made using a tidal-zone model obtained from the National Oceanic and Atmospheric Administration (NOAA) with values referenced to the Sandy Hook tide station 8531680 (Christina Urizar, NOAA, written commun.; fig. 6). Verified Sandy Hook water-level data (Greenwich Mean Time (GMT) and MLLW) downloaded from the NOAA tides and currents Web page were adjusted for time and amplitude for each polygon zone. The tide-zone model polygon file was overlain with the survey trackline map in a Geographic Information System (GIS) - ESRI ArcGIS 10.3 - and the appropriate NOAA tidal-zone name, assigned by trackline, was appended to all data points as an attribute. Where data along a single trackline crossed over multiple zone boundaries, they were separated into their respective zones by time. Elevation corrections were applied to the $x, y, z$ data based on the date-time and appropriate tidal zone using lookup tables created with Microsoft Excel. Original seismic data in this study were collected in the WGS84 UTM Zone 18N coordinate system. Transforma-

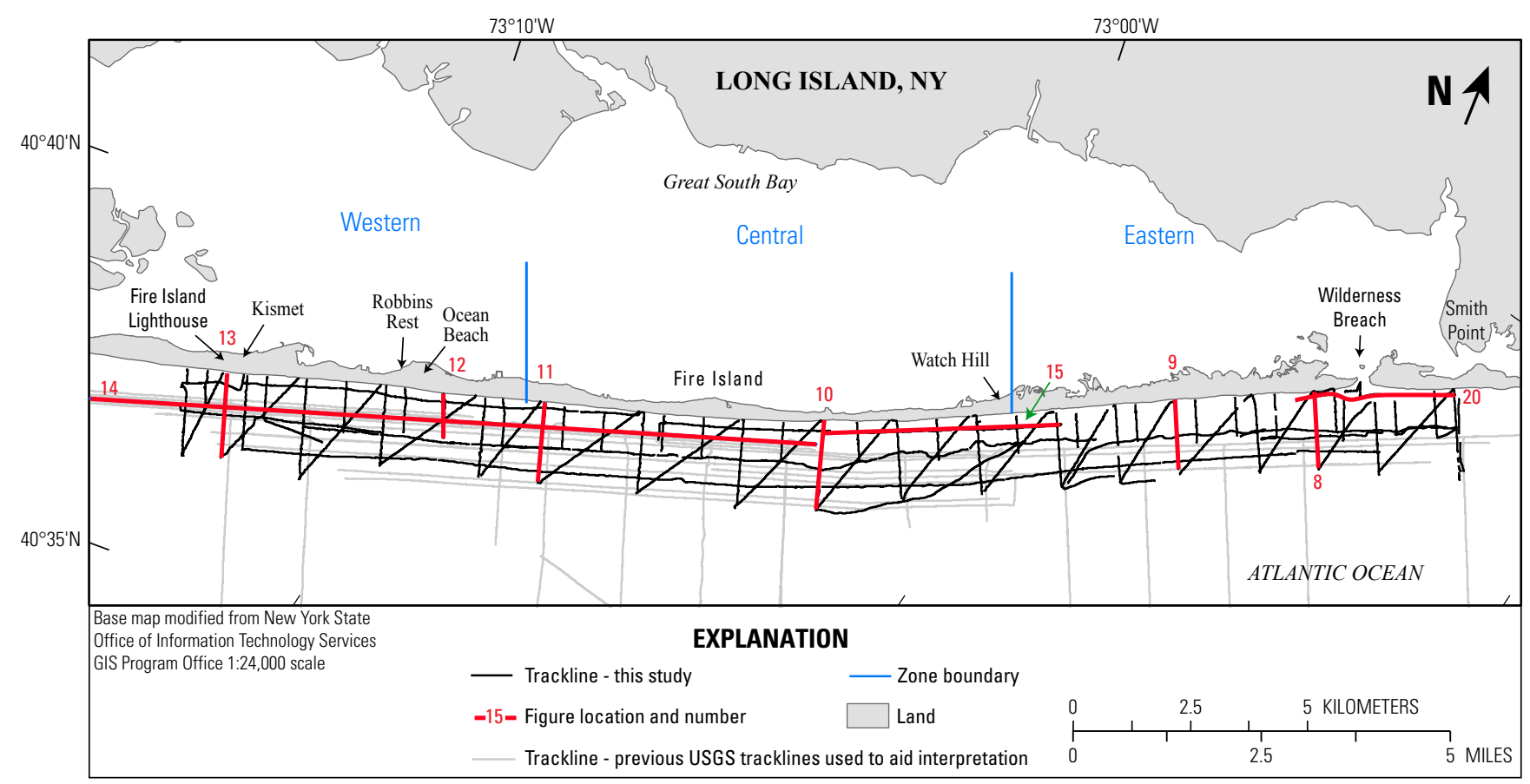

Figure 5. Trackline coverage of chirp subbottom data collected in 2014 by the U.S. Army Corps of Engineers and selected U.S. Geological Survey (USGS) trackline coverage from 2011 and 2014 (Denny and others, 2015b; Schwab and others, 2016) used to guide horizon correlations for this study. Locations of chirp profiles presented in this report are shown in red. 


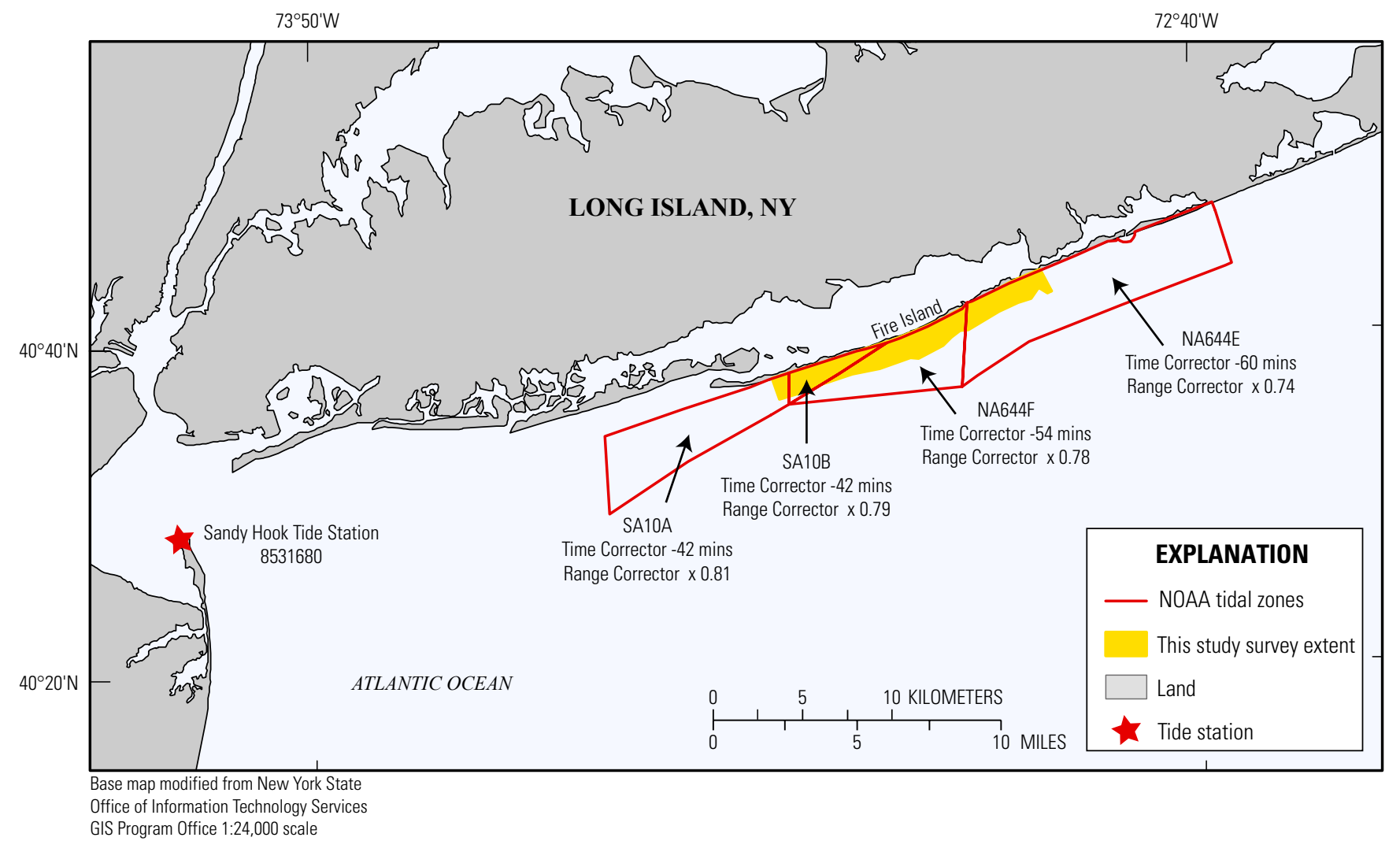

Figure 6. National Oceanic and Atmospheric Administration (NOAA) tide zones referenced to Sandy Hook tide station with associated corrector values. Time is expressed in minutes (mins).

tions to horizontal projection NAD83 UTM Zone 18N and vertical datum NAVD 88 (GEOID09) were done using NOAA's free software, VDatum version 3.6.

Isopach and structure contour maps were gridded in Golden Software's Surfer version 13 using the nearest neighbor interpolation option, employing an anisotropy ratio of 0.5 and angle -70 (ellipsoid rotated counterclockwise 70 degrees), and a $25-\mathrm{m}$ cell size. The rotated ellipsoid search was needed to better project sediment-thickness trends between the relatively wide-spaced chirp profiles and to favor the shore-parallel thickness trend present in the nearshore-bar system.

\section{Results}

Below the inner shelf and lower shoreface, a well-defined erosional unconformity (reflector R0) is interpreted as the base of the Holocene transgressive section (figs. 7-13). R0 is easily identified on the inner shelf and is correlative with the base of the Holocene as interpreted by Schwab and others (2013, 2014b, 2016). R0 truncates underlying glacial outwash deposits (see Schwab and others, 2013) and is overlain by a mix of onlapping and downlapping Holocene shoreface sediment. Landward of the shoreface toe, R0 commonly bifurcates into multiple reflectors, including R1 and R2, as mapped in this study (fig. 7). This bifurcation point occurs progressively farther seaward, from east to west, within the western zone (figs. 11-13). R0 also bifurcates into R1 and R2, moving westward alongshore, near the boundary of the central and western zones (fig. 14). Identification of R1 across the central zone is difficult because of cut and fill structures, insufficient data coverage relative to the complexity of the geology, and inadequate seismic penetration (fig. 15). 


\section{Stratigraphic Framework}

\section{Landward}

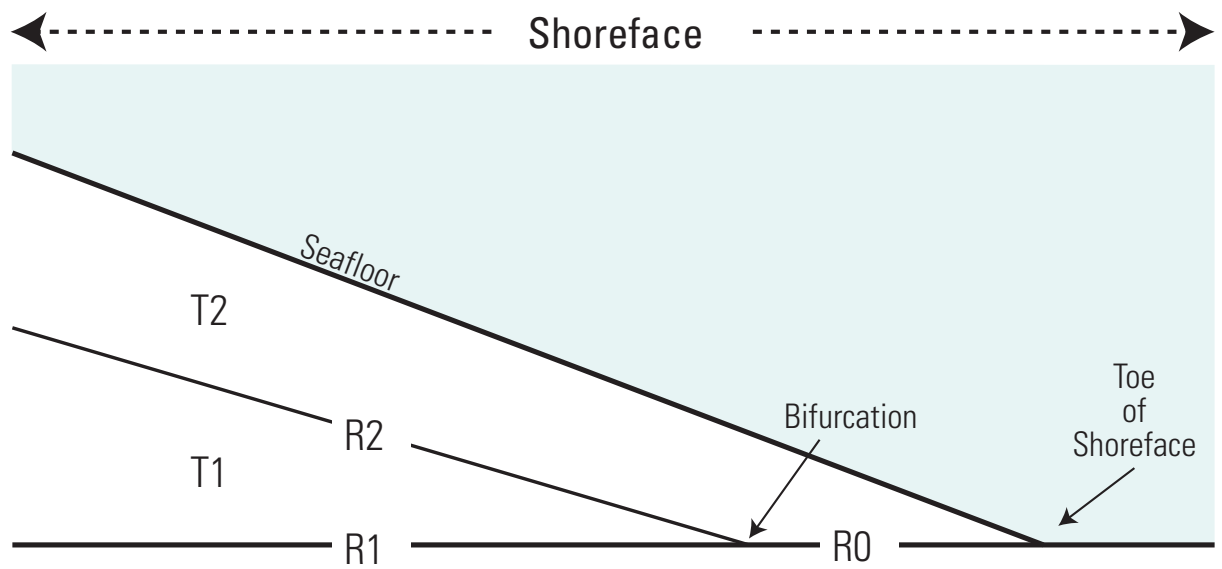

Figure 7. Schematic of naming conventions used for subsurface boundaries and sediment thickness maps. Horizon R0 bifurcates into R1 and R2 toward the west and landward. T1 and T2 are Holocene sediment sections. The full Holocene sediment thickness map (fig. 18) is the section from R0+R1 to the seafloor (T1+T2). T2 is the active shoreface section (fig. 19).
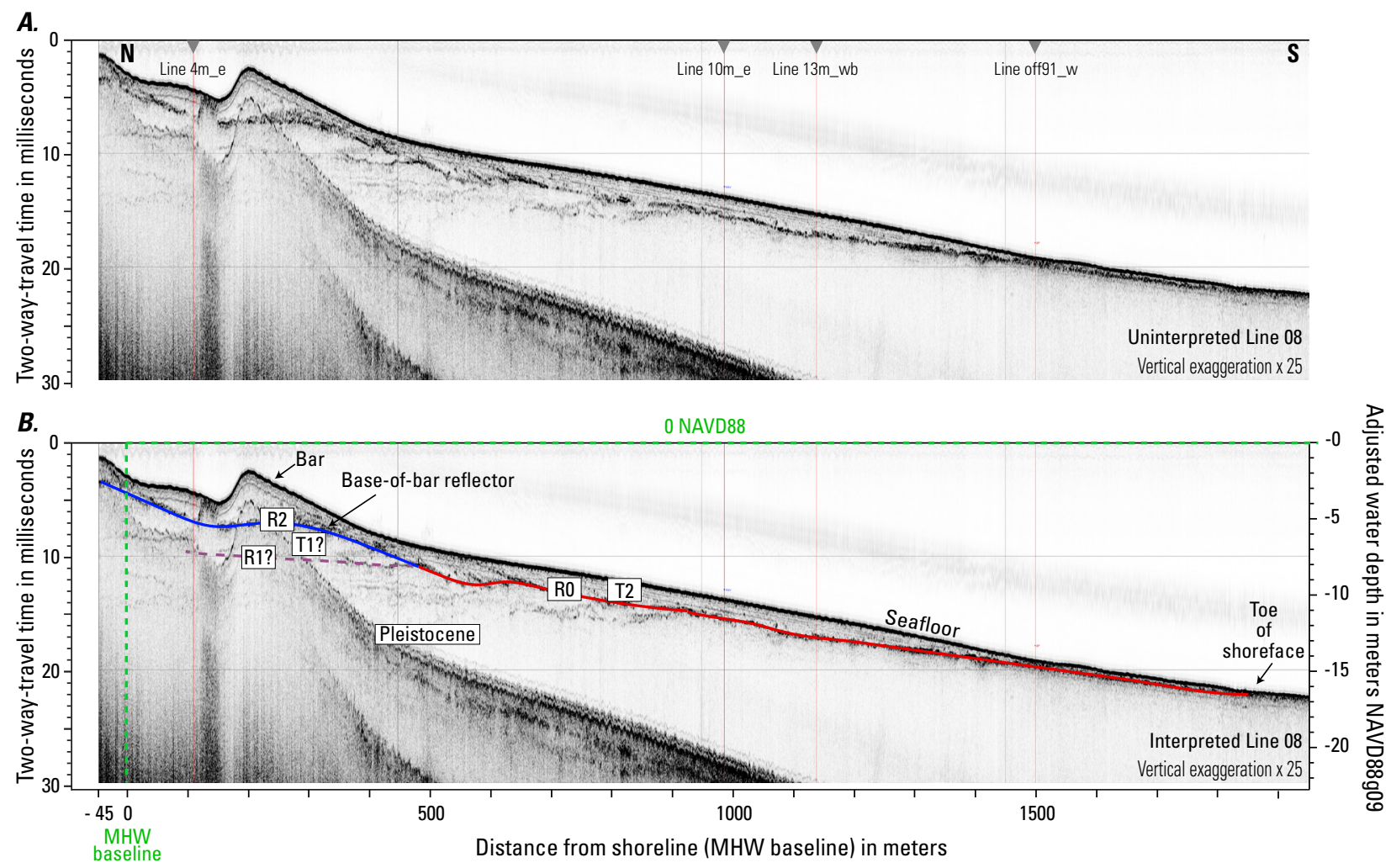

Figure 8. Chirp profile 8 from the eastern end of the study area showing relatively thin Holocene section. $A$ shows uninterpreted profile and $B$ shows interpreted profile. A possible R1 extension of the basal Holocene boundary is shown below the bar. A crossing alongslope chirp profile ( $\left.4 \mathrm{~m} \_\mathrm{e}\right)$ slightly landward of the bar includes sediment from the western side of the Wilderness Breach ebb tidal delta shown in figure 20. In all chirp profile figures, green dashed lines indicate the location of the operational mean high water (MHW) baseline and position of sea level at 0 meters NAVD 88 (GEOID09). Location of profile is shown in figure 5. Mean high water is abbreviated as MHW. 


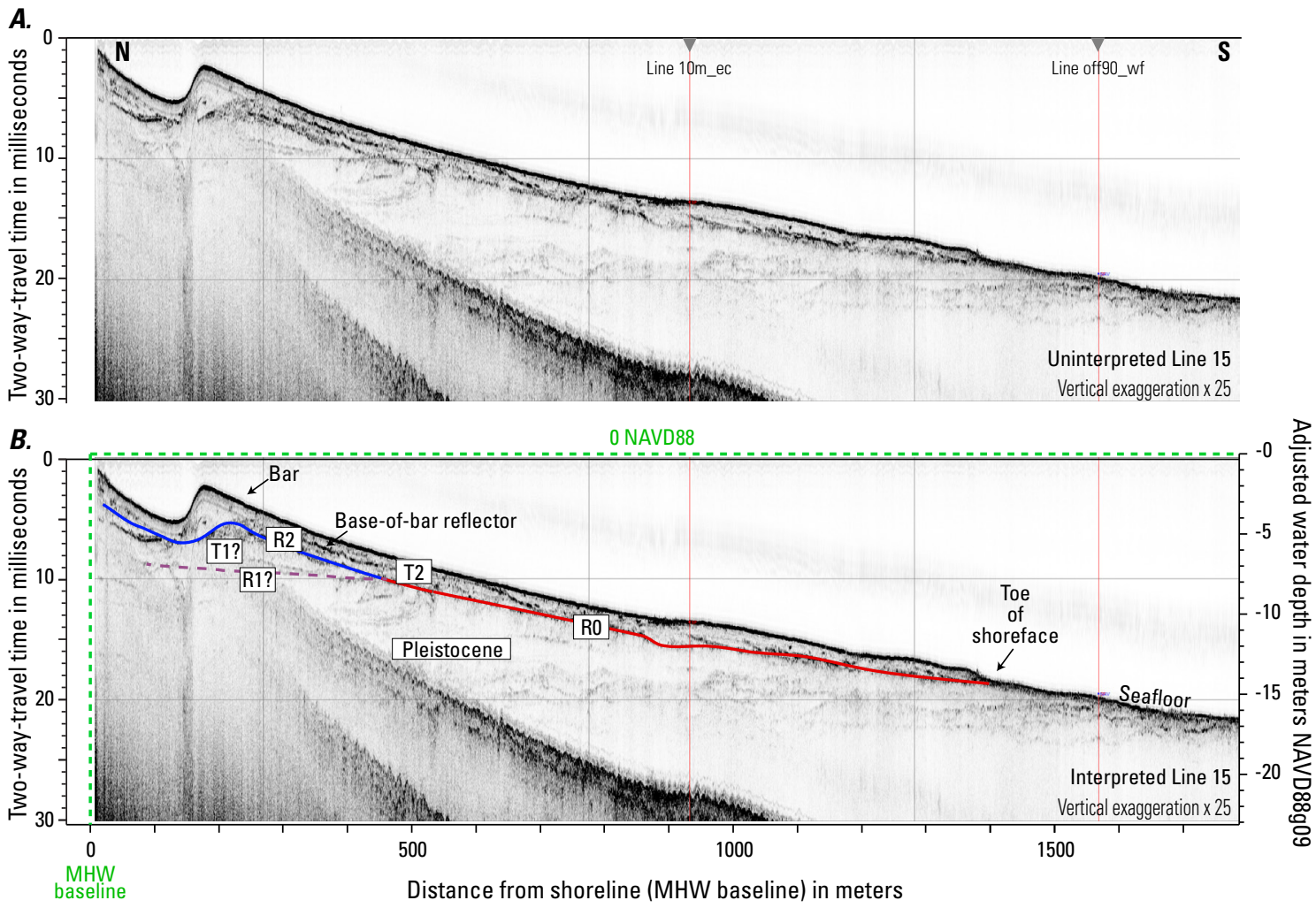

Figure 9. Chirp profile 15 from the eastern zone illustrating the thin shoreface sediment in this area. A shows uninterpreted profile and $B$ shows interpreted profile. Distinguishing the boundary between Holocene and Pleistocene sections nearshore is difficult without borehole control or better stratigraphic criteria. Location of profile is shown in figure 5. Mean high water is abbreviated as MHW.
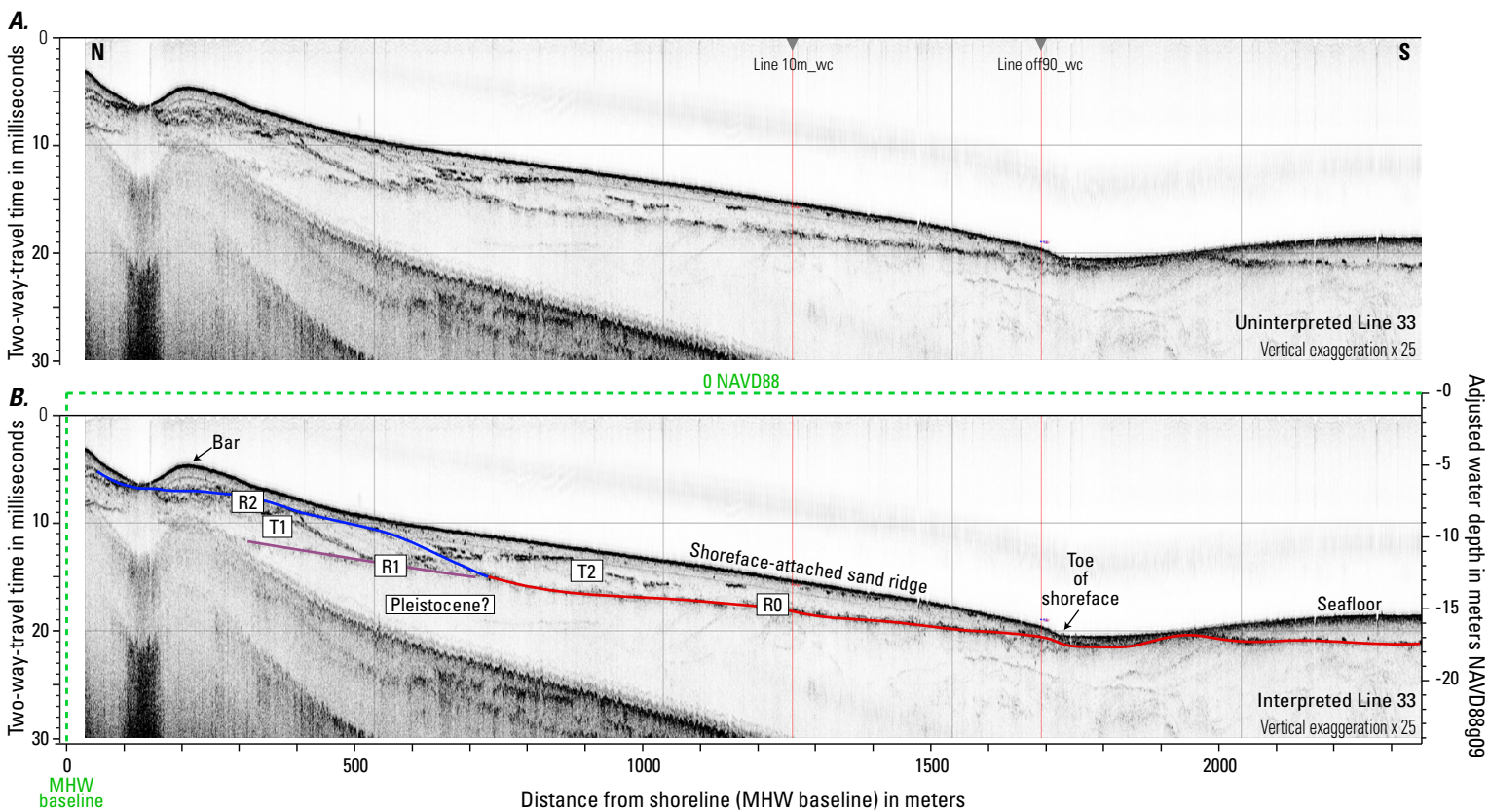

Figure 10. Chirp profile 33 from the central zone. Prograding units within T1 may represent reworked ebb-tidal deltas. $A$ shows uninterpreted profile and $B$ shows interpreted profile. Note discontinuous high-amplitude reflectors within $T 2$, which could indicate buried troughs related to shoreface-attached sand ridges. These high-amplitude reflectors are discontinuous alongslope. A shoreface-attached sand ridge is incorporated in T2 within the lower shoreface. Location of profile is shown in figure 5. Mean high water is abbreviated as MHW. 

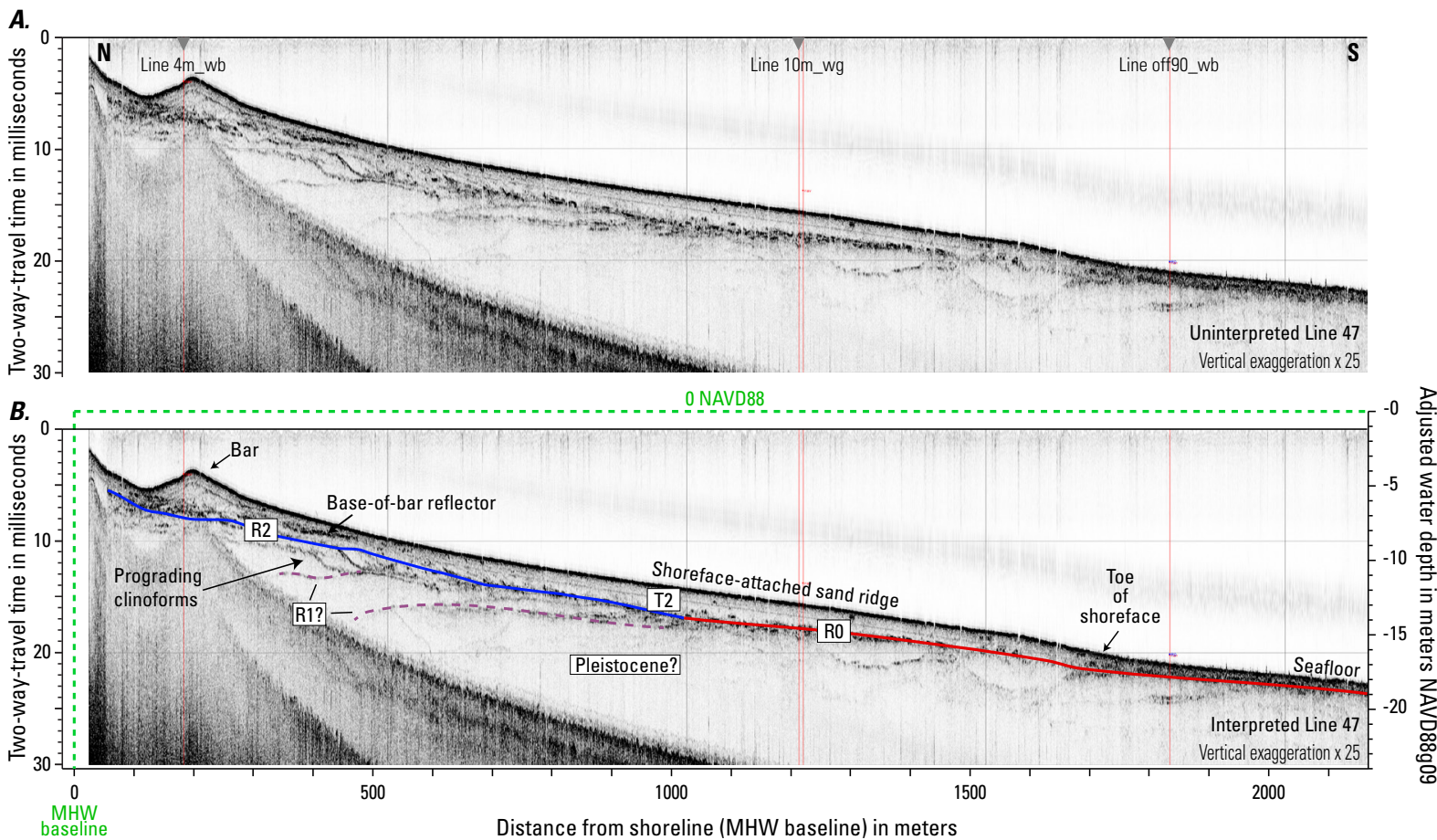

Figure 11. Chirp profile 47 from the central zone. A shows uninterpreted profile and $B$ shows interpreted profile. Prograding structures are present in the upper shoreface below R2 that could indicate reworked ebb-tidal deposits. Below the prograding units, the base of the Holocene is uncertain (R1?), but could include former Holocene inlet fill above the lowermost landward dipping reflector. A shoreface-attached sand ridge is incorporated in T2 within the lower shoreface. Location of profile is shown in figure 5. Mean high water is abbreviated as MHW.

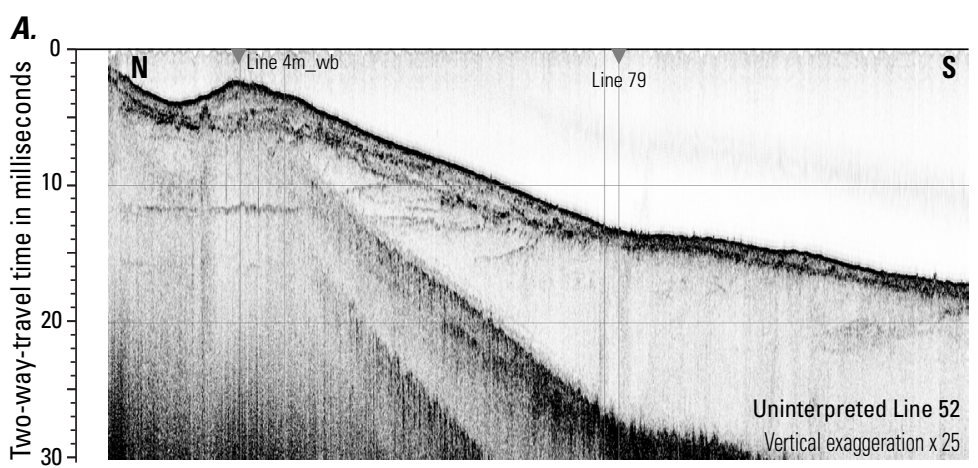

B.

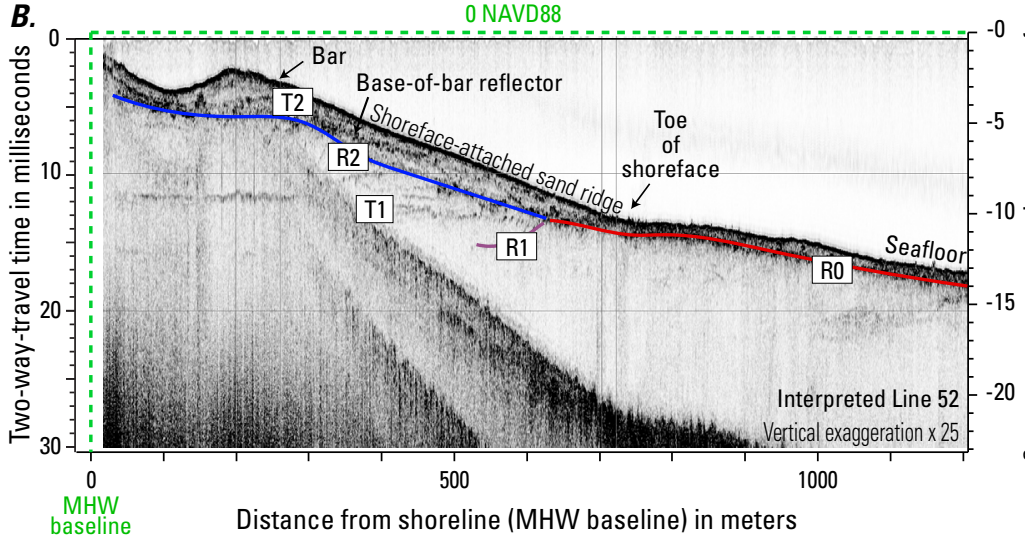

Figure 12. Chirp profile 52 from the eastern side of the west zone. A shows uninterpreted profile and $B$ shows interpreted profile. This location illustrates where the lower R1 horizon changes character from flat-lying in the west, to a landward-dipping reflector that could be related to a buried inlet. This profile is slightly landward of a large borrow pit (fig. 18). The reflection-free zone below R0 is correlated to the Pleistocene outwash lobe of Schwab and others (2014a). Location of profile is shown in figure 5 . Mean high water is abbreviated as MHW. 

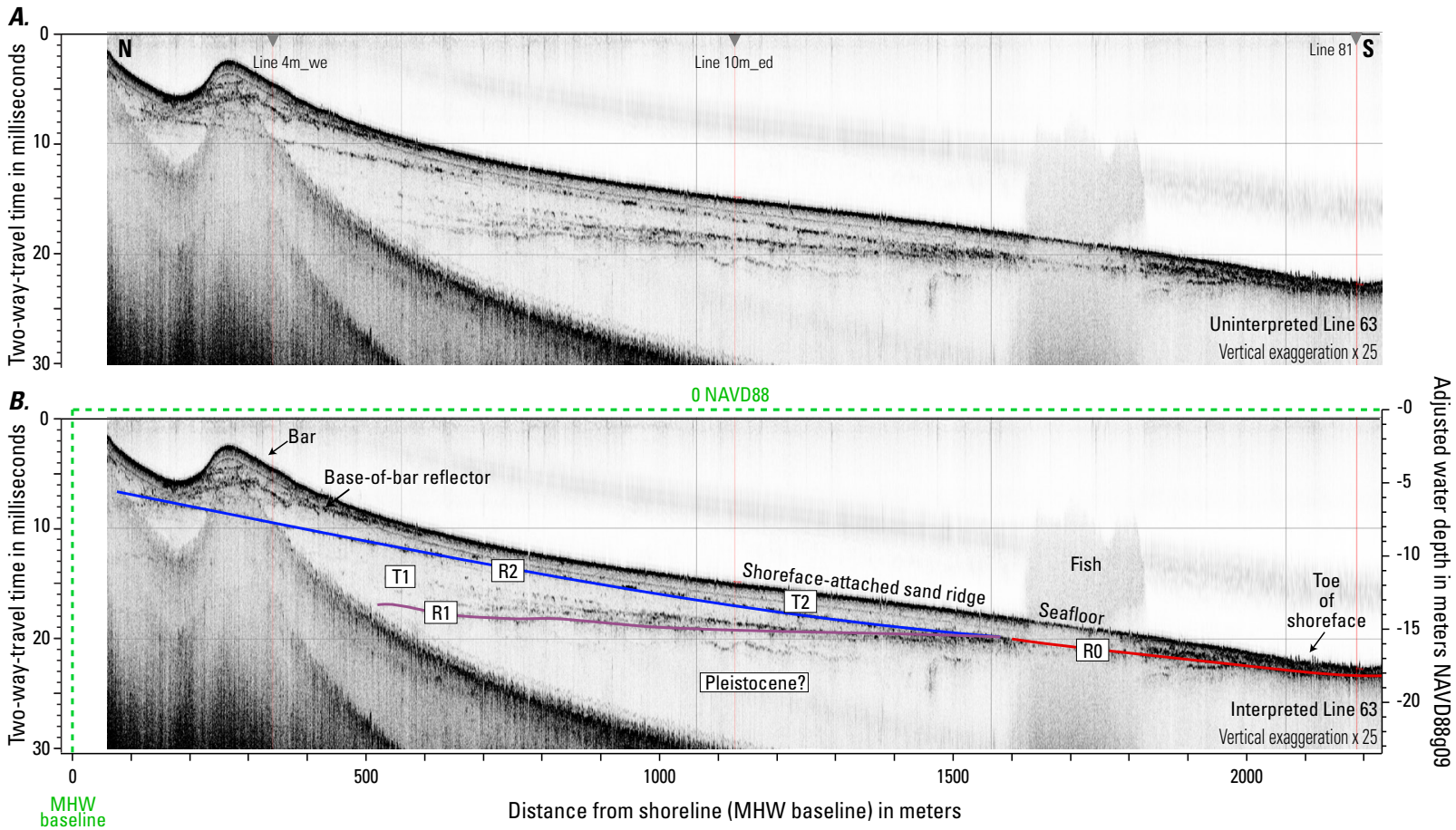

Figure 13. Chirp profile 63 from the western end of the study showing the wedge of T1 sediment between R1 and R2. A shows uninterpreted profile and $B$ shows interpreted profile. This profile is representative of the west zone. Note the T1 section downlaps seaward. A crossing tie-line in about $11 \mathrm{~m}$ water depth (see fig. 14) shows this T1 section also progrades westward. Location of profile is shown in figure 5. Mean high water is abbreviated as MHW.
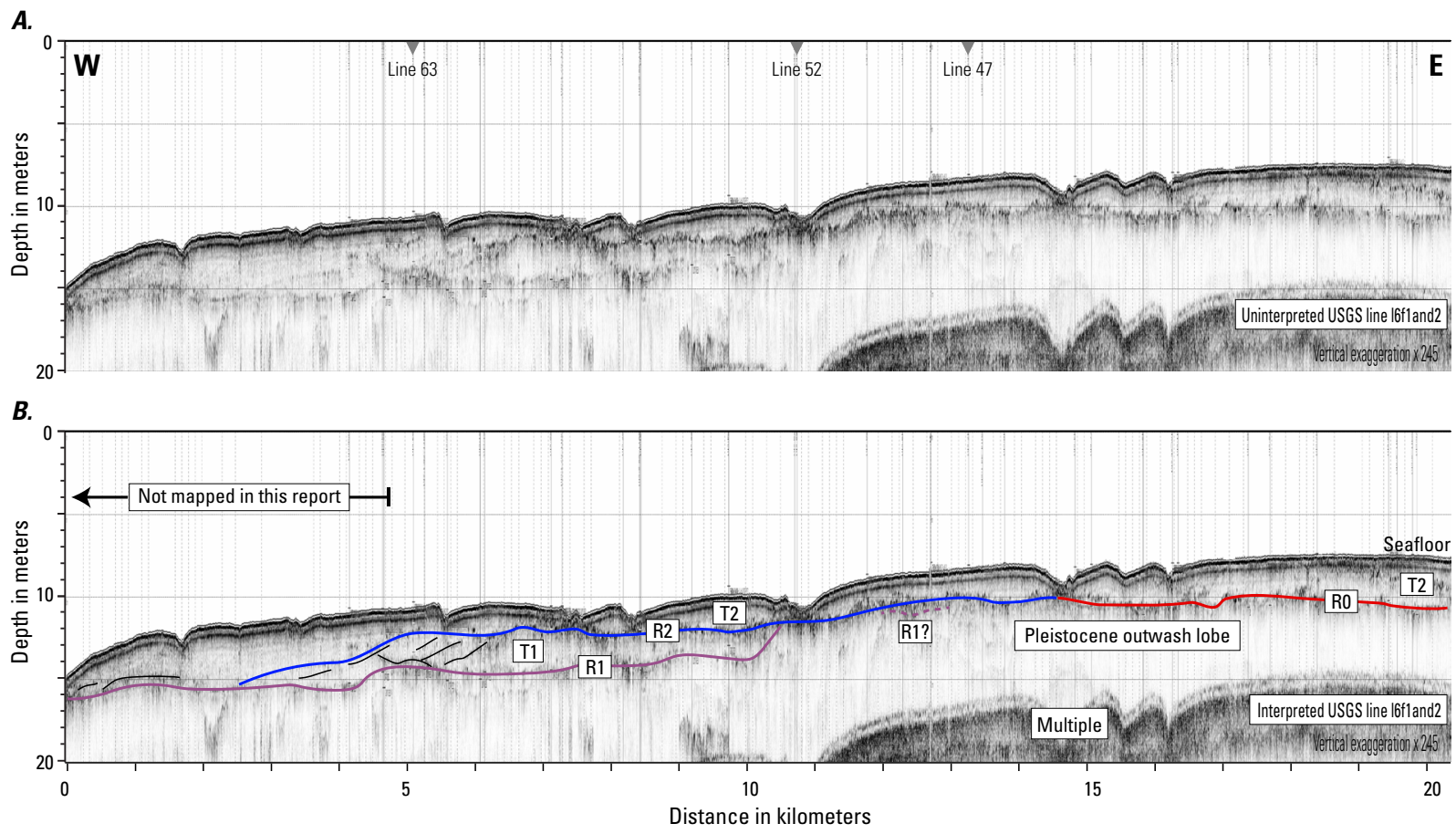

Figure 14. Alongshore chirp profile from a previous survey carried out by the U.S. Geological Survey in the central and western zone showing the bifurcation of R0 to R1 and R2 crossing the western margin of the Pleistocene outwash lobe. The westward progradation of T1 and T2 sediment is attributed to the westward migration of Fire Island Inlet. $A$ shows uninterpreted profile and $B$ shows interpreted profile. Location of profile is shown in figure 5. 
Reflector R1 is interpreted to be the basal Holocene boundary that extends R0 landward below a thickening shoreface. R1 and R2 (higher in section) always extend from the same point of bifurcation, thus creating two mapped horizons: R0+R1 and R0+R2 (figs. 16 and 17). The sediment sections bounded by R1-to-R2 and R0+R2-to-seafloor define two Holocene sections: T1 and T2 (fig. 7). In this report, isopach maps are presented for the full Holocene section (T1+T2) and the upper T2 section (figs. 18 and 19).

The structure contour map for R0+R1 (base of Holocene) shows this boundary is shallower in the east, reaching 5-6 m below sea level (NAVD 88, GEOID09) near the shoreline, and extends deeper in the west, reaching a depth of 15-16 m nearshore (fig. 16). In the central zone, it is often difficult to determine with confidence which reflectors might be R1. First, the section between R1 and R2 often exhibits a lensing architecture in the central zone, primarily due to undulations in reflectors below R2 (fig. 15). Second, a clear distinction between Holocene and Pleistocene material is difficult because of acoustic similarities in the stratigraphy of Holocene and Pleistocene glacial outwash sediments (fig. 12). Finally, at the water depths in which some distinction might be made, the stratigraphy is often masked by the bottom multiple, preventing the mapping of R1. Closer-spaced subbottom profiles and subsurface stratigraphic control (for example, sediment cores) are needed to better identify the base of the Holocene in the central zone.

Reflector R2, in combination with R0, represent the base of an uppermost sediment section (T2) mapped across the entire study area. The section above R2 is thinner toward the east, where R2 is mapped below a zone of high-amplitude reflections below the nearshore bar (figs. 8-11). The structure contour map to R0+R2 shows less change in elevation from east to west. Depths (NAVD 88, GEOID09) below sea level at the shoreline for $\mathrm{R} 0+\mathrm{R} 2$ reach 4-5 $\mathrm{m}$ in the east and remain relatively uniform toward the west, until the western zone, where it deepens to 8-9 m nearshore (fig. 17).
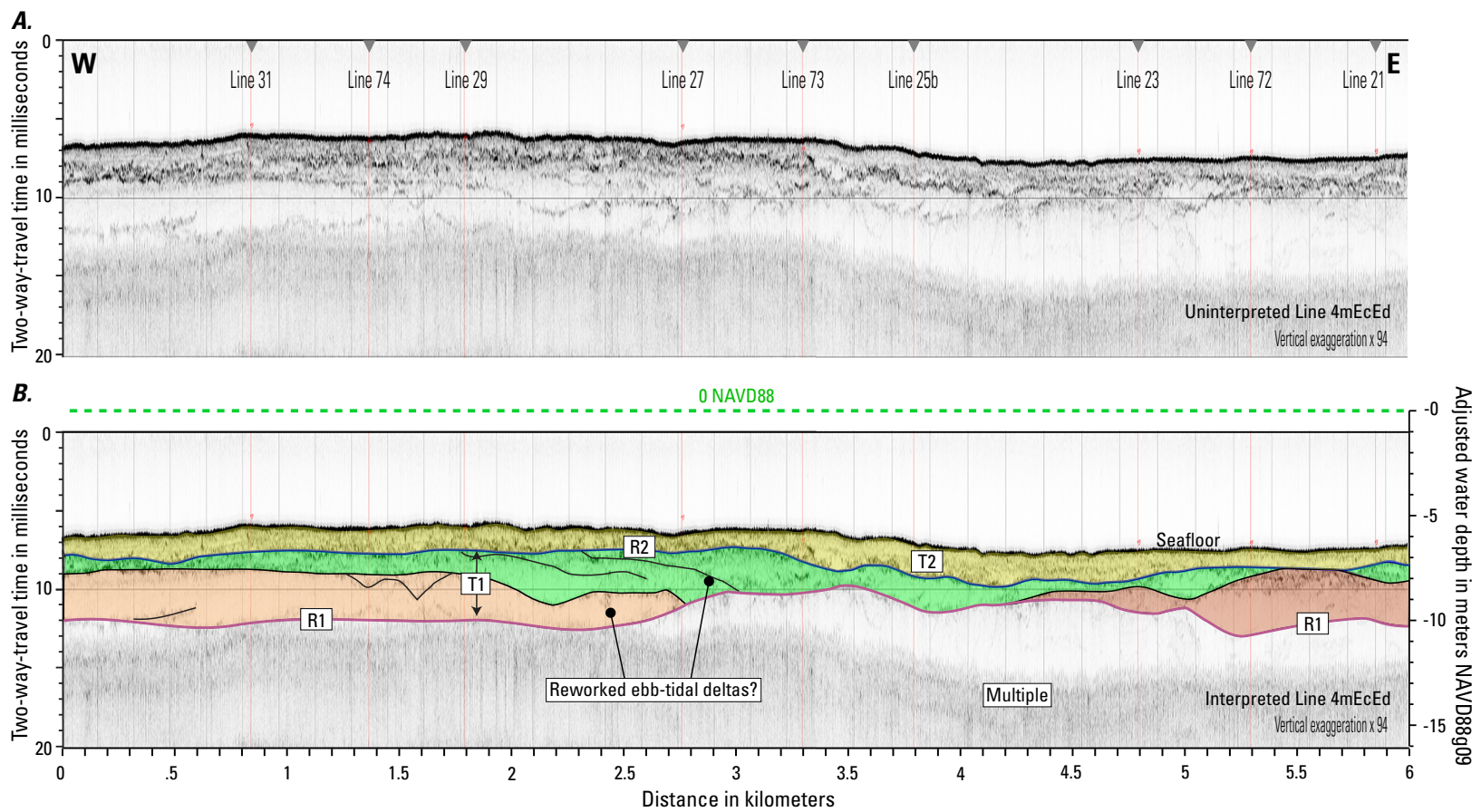

Figure 15. Alongshore chirp profile in about 6 meters of water illustrates the complex sedimentary units that comprise the T1 section in the central zone. $A$ shows uninterpreted profile and $B$ shows interpreted profile. The colored units in $T 1$ form southwest prograding clinoforms in dip-oriented profiles (figs. 10 and 11). This lensing architecture and poor acoustic resolution, due in part to the bottom-multiple interference, make identification of the basal Holocene boundary difficult across this central zone. Location of profile is shown in figure 5 . 


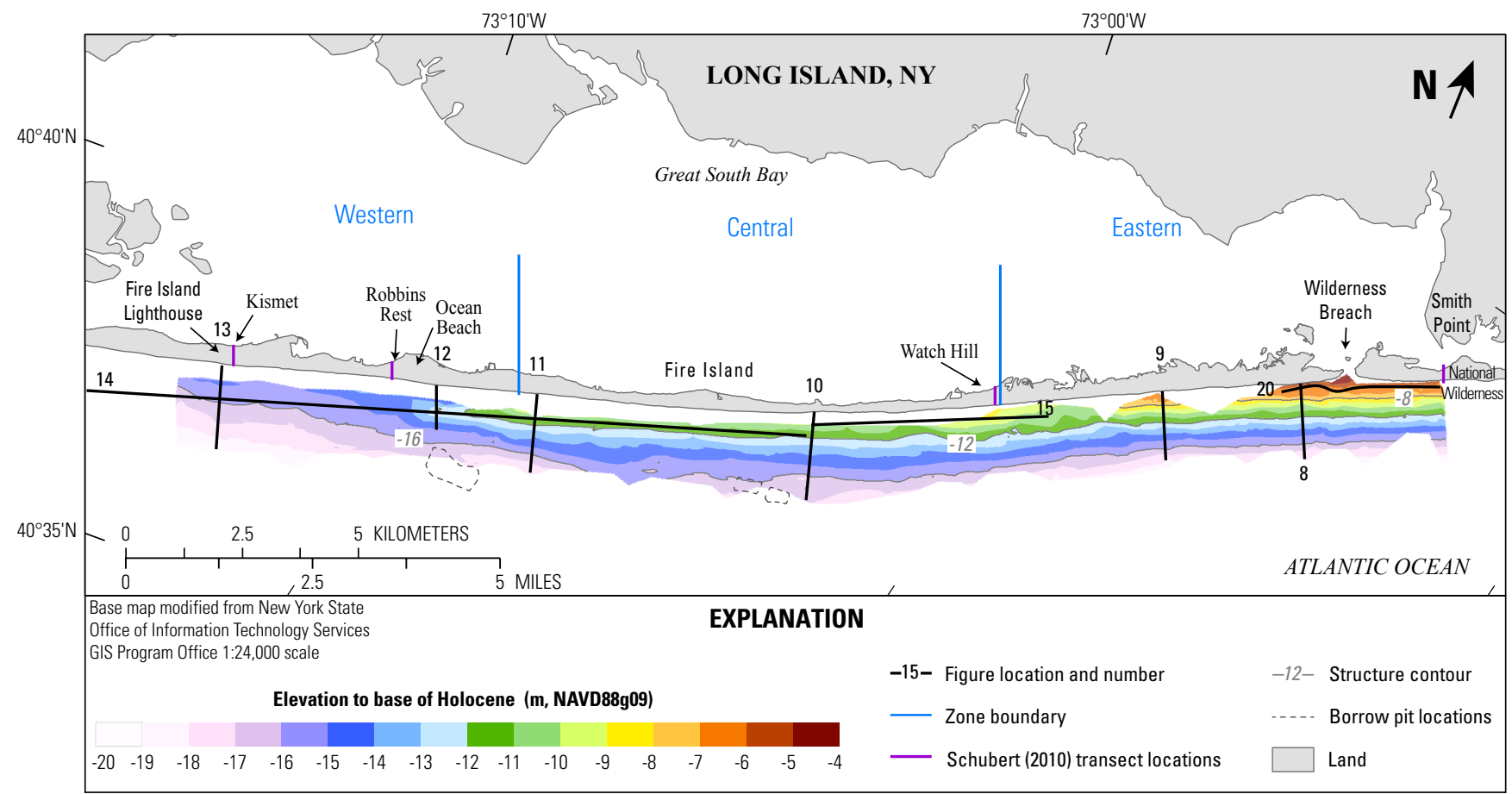

Figure 16. Structure contour map showing elevation of the base of Holocene (R0+R1 horizon). The blank area close to the beach is not mapped due to a gap in correlating the lower R1 horizon through the bottom multiple and attenuation of acoustic energy below and landward of the nearshore bar. Seaward of Ocean Beach, the 10-12 meter $(\mathrm{m})$ depth contours turn back to the east on the landward edge of the map indicating a possible buried inlet channel structure (see R1 reflector in figure 12).

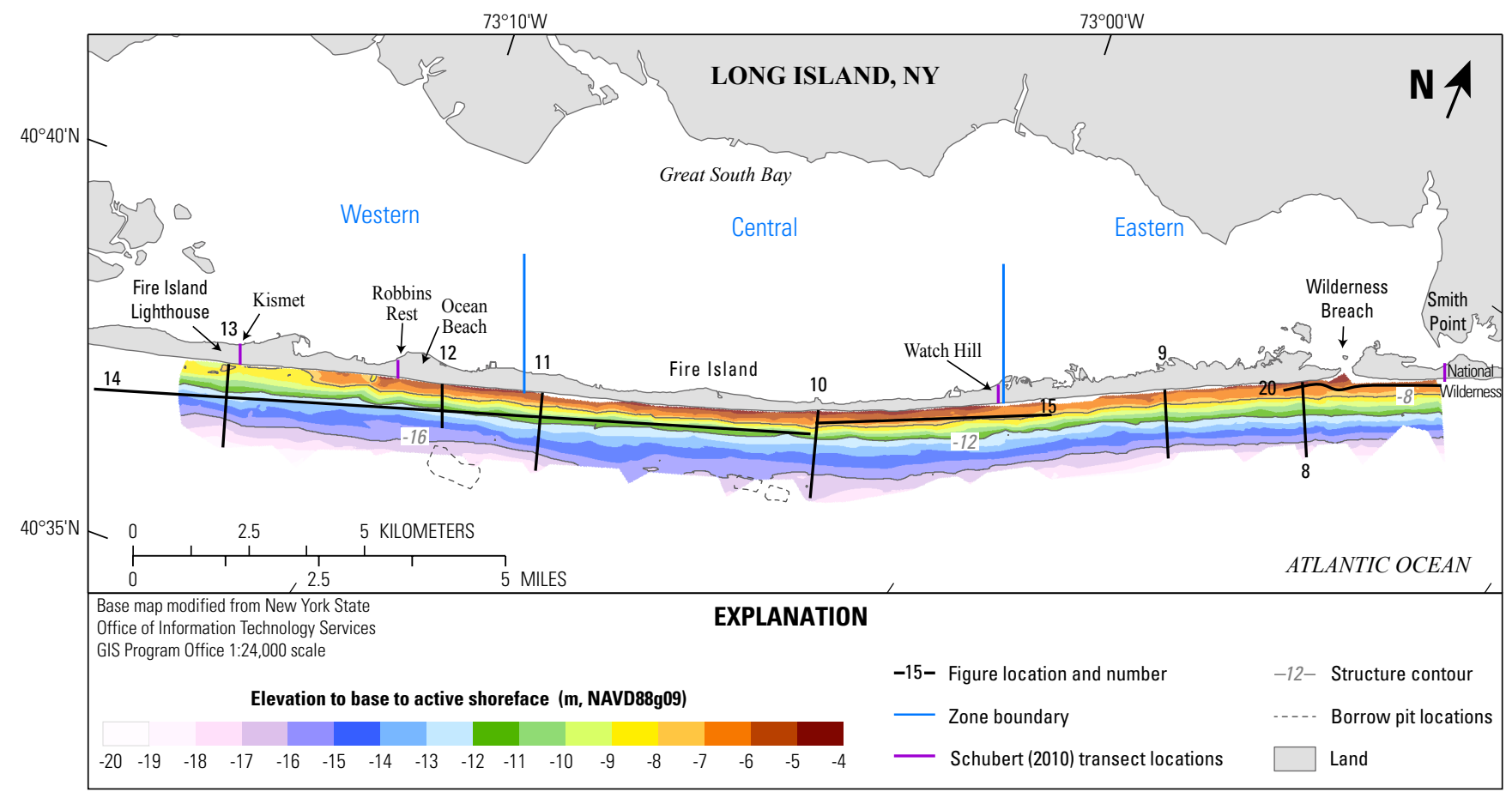

Figure 17. Structure contour map showing elevation of the R0+R2 horizon (base of T2). This boundary underlies the shorefaceattached sand ridges and nearshore bar system. Elevation is indicated in meters $(\mathrm{m})$. 


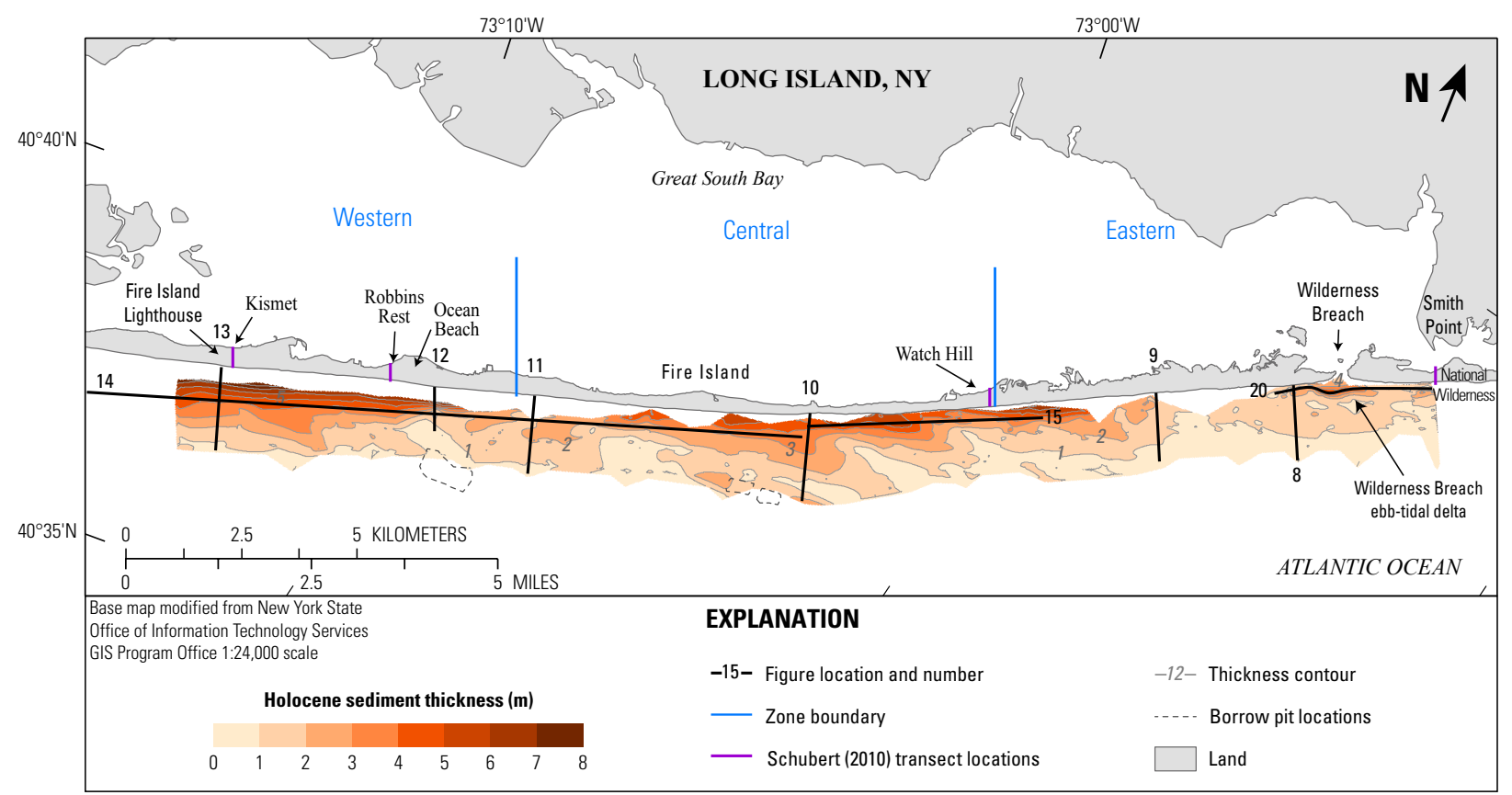

Figure 18. Map of Holocene sediment thickness illustrates the influence of shoreface-attached sand ridges and landward thickening shoreface on overall thickness patterns. The noticeable northwest-to-southeast trend reflects shoreface-attached sand ridge thickness. The landward extent of this map is limited by where the R1 horizon is mapped. The sediment contained in the nearshorebar system is partially reflected along the landward edge of this map. There is no difference between the full Holocene isopach and the T2 isopach where only R0 is mapped across the lower shoreface and eastern zone (compare figures 18 and 19). Holocene sediment thickness is indicated in meters $(\mathrm{m})$.

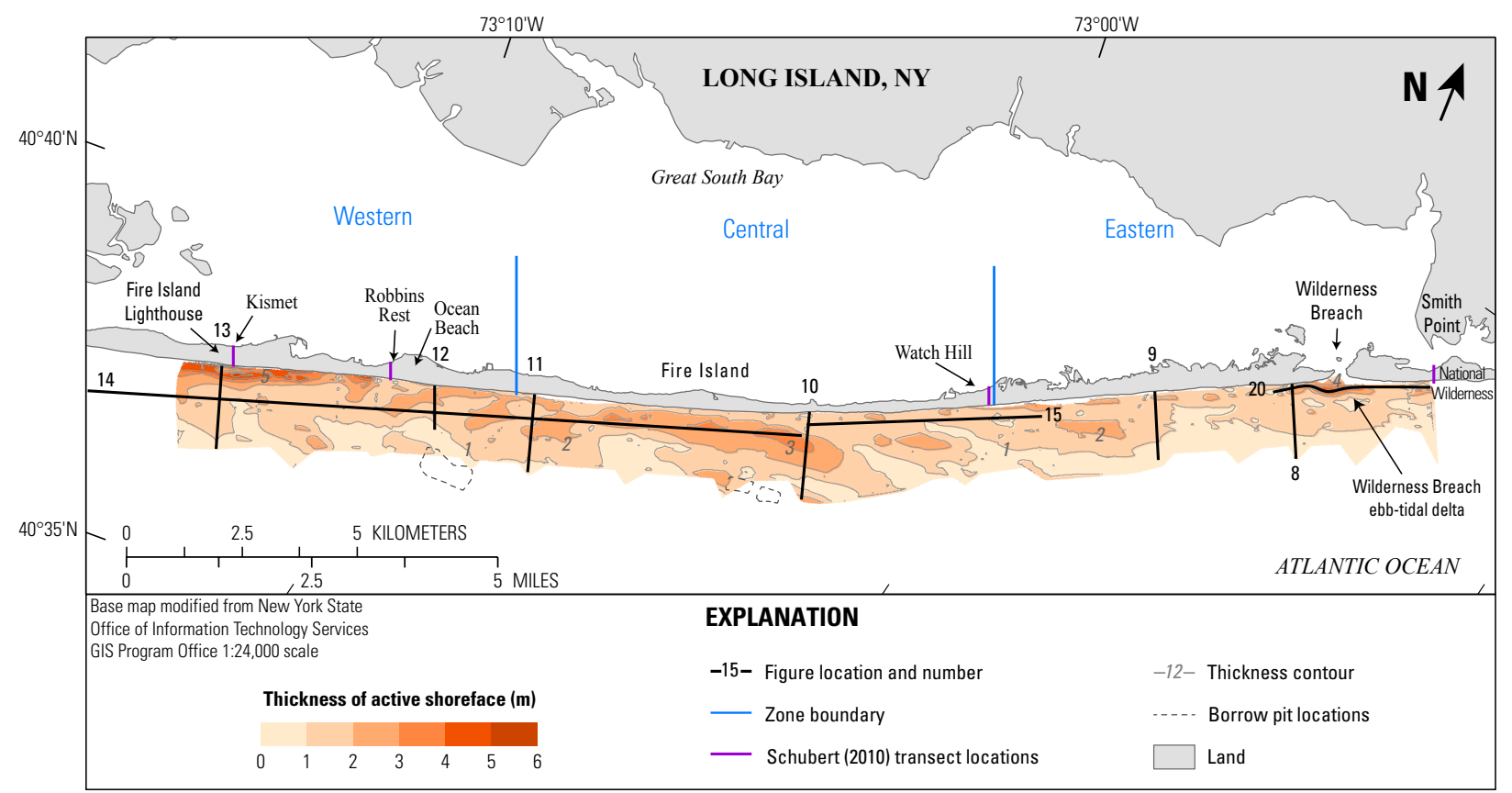

Figure 19. The T2 isopach map illustrates an overall thinning section from west to east. Much of the eastern zone and lower shoreface areas are the same thickness as the full Holocene isopach map (areas where only R0 is mapped). Thicker sediment volume is related to shoreface-attached sand ridges and the nearshore-bar system in the west zone, primarily shoreface-attached sand ridges in the central zone, and the wilderness breach ebb-tidal delta that blends with the nearshore-bar in the east zone. Thickness of active shoreface is indicated in meters $(\mathrm{m})$. 
The upper T2 section (fig. 19) is usually thickest in association with the shore-parallel bar, which commonly exhibited $2 \mathrm{~m}$ or more of relief (trough to bar crest) at the time of the survey. The T2 sediment volume is greatest across the central and west zones, where it includes the sediment volume associated with the northwest-to-southeast trending shoreface-attached sand ridges (fig. 19). Shorefaceattached sand ridges are embedded within the T2 section (figs. 10-11) but are distinguished only by the surficial topographic relief trends shown by the inner-shelf bathymetry (fig. 3). In the central zone, several shoreface-attached sand ridges with thicknesses of $2 \mathrm{~m}$ or more dominate the thickness pattern, which is oblique to the shoreline and oriented northwest-to-southeast (fig.19). Closer to shore, in $10 \mathrm{~m}$ or less water depth, the T2 section thins where the base of T2 (R2) is mapped over the top of prograding clinoforms in the lower T1 section (figs. 10 and 15). T2 is thinner in the eastern zone except for the wilderness breach ebb-tidal deposit that was being shaped into a shore-parallel depocenter at the time of this survey (fig. 20). In the west zone, a relatively planar R2 boundary and a thicker nearshore bar result in the thickest nearshore section mapped (fig. 19). The T2 unit is internally characterized by highamplitude, discontinuous reflection surfaces not correlated between lines, perhaps indicating localized storm-erosion events and reworking (fig. 10). A base-of-bar reflector is common across the study area within the upper T2 section and is characterized as a high-amplitude reflector below the nearshore bar (figs. 8-9 and 11-13). This reflector commonly outcrops at the seafloor in approximately $7-9 \mathrm{~m}$ water depth and is considered a diagnostic feature of the active shoreface section (T2).

The full Holocene isopach map shows the sediment thickness to the extent that the base of the Holocene (R0+R1) can be mapped landward below the shoreface (fig. 18). The Holocene (T1+T2) thickens toward the beach, reaching 8-9 $\mathrm{m}$ in the western zone at a distance of $500 \mathrm{~m}$ from the pres-
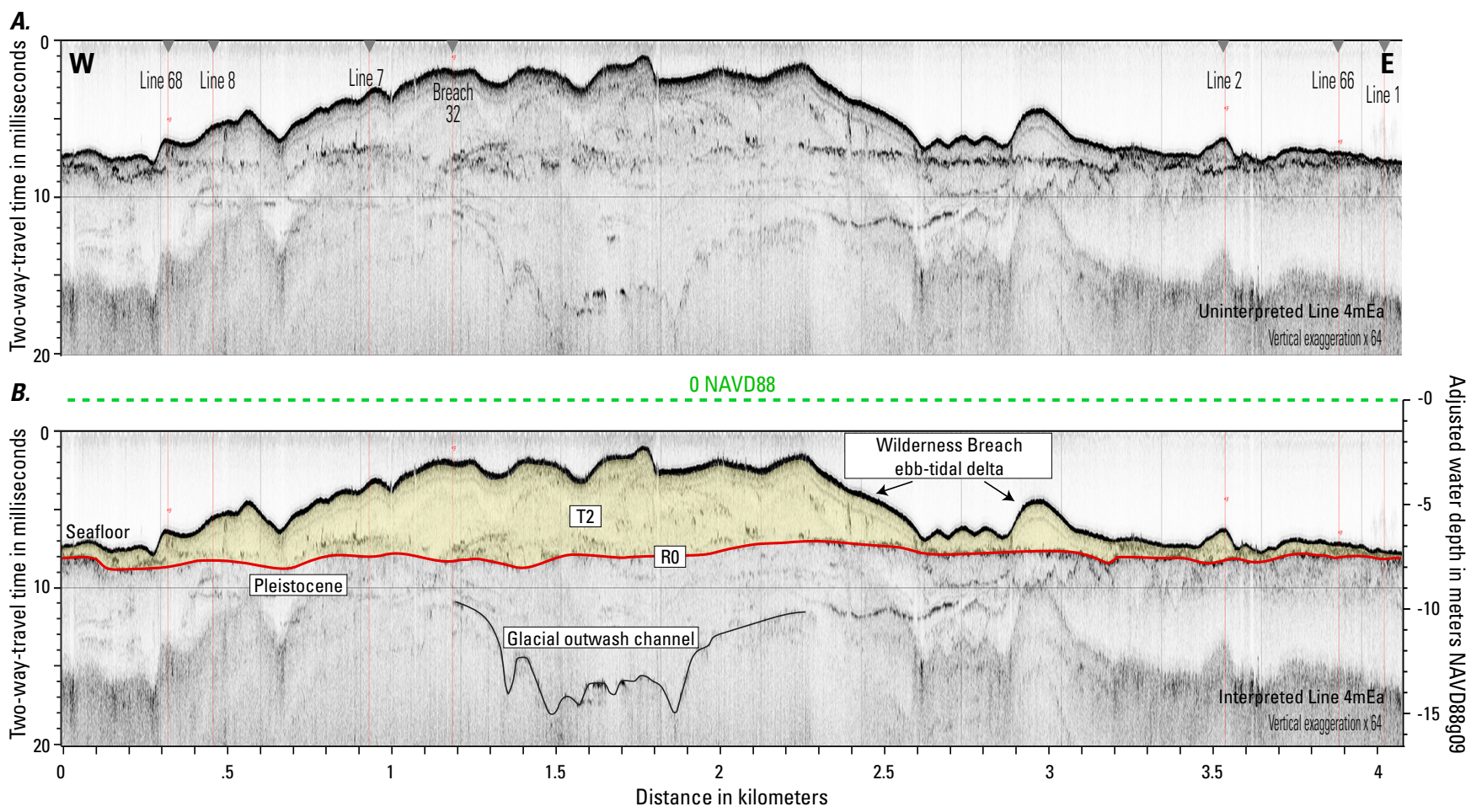

Figure 20. Chirp profile from the eastern zone that crosses the wilderness breach ebb-tidal delta, running parallel to shore. This deposit is being reworked. The character of the thin Holocene section in this area, prior to the breach, is observable on the east and west sides of this deposit. A crossing shore-normal chirp profile (line 8, left side of figure) in shown in figure 8. Location of profile is shown in figure 5. 
ent shoreline, before the R1 boundary is obscured by the bottom multiple (fig. 13). The lower T1 section accounts for much of the thicker Holocene section in the western and central zones. However, the stratigraphic architecture within T1 is different between the west and central zones. In the western zone, the landward-thickening T1 section contains stacked wedge-shaped depositional units that thin seaward (fig. 13) and downlap toward the west (fig. 14). In contrast, the central-zone T1 section contains overlapping deposits of varying thickness alongslope (fig. 15) that appear as prograding clinoforms in dip profiles (figs. 10 and 11). In the east zone, the T1 section might be thin or absent (figs. 8 and 9).

\section{Discussion}

The objective of this study is to characterize nearshore geology and determine nearshore sediment thickness, up to the shoreline, at Fire Island. In particular, we wanted to estimate the thickness of sediment that was, or could be, reworked or mobilized on interannual to decadal time scales. The T2 sequence mapped in this study is interpreted as an inventory of this most-active section. Additionally, the spatial differences in the nearshore stratigraphy broadly correspond to three geomorphic zones along Fire Island, which were identified previously by other investigators (fig. 19). The eastern, central, and western zones exhibit differences in shoreline change (erosion and accretion) linked to alongshore sediment budgets (Kana, 1995; Kana and others, 2011; Lentz and others, 2013; Hapke and others, 2010, 2013, 2016) and inner-shelf geologic framework (Schwab and others, 2000, 2013, 2014a).

\section{Sediment Distribution Patterns}

T2 encompasses the nearshore-bar system and shoreface-attached sand ridges, which are primary controls on sediment thickness patterns. The T2 section thickens from $0 \mathrm{~m}$, where the toe of the shoreface may coincide with a trough between sand ridges, to a maximum of $7.3 \mathrm{~m}$ in the western zone, below the nearshore bar (fig. 13 and 19). In most areas, a base-of-bar reflector clearly crops out on the seafloor in 7-9 m water depth, suggesting truncation of this stratigraphic horizon at the seafloor (figs. 11 and 13). In other locations, the base-of-bar reflector is not observed or does not reach the seafloor (figs. 8-10). The stratigraphic relationship between the alongshore bar system and shoreface-connected sand ridges suggests that in some places the bar appears to overlie the sand ridges where the two features merge (fig. 13), while in other places the bar and ridge features merge without any acoustic distinction.

In the western zone, the nearshore-bar thickness and offshore sand ridges are apparent in the T2 isopach. T2 thickness in the western zone is consistent with the shoreline stability reported in other studies (Hapke and others, 2010, 2016; Schwab and others, 2013). In the central zone, the nearshore bar, while present, is less significant, and the offshore sand ridges are clearly defined by the isopach map (fig. 19). The large shoreface-connected sand ridge in the central zone (>3 m deposit, figs. 11 and 19) is consistent with stable or advancing long-term shoreline change in this area (Hapke and others, 2010, 2016; Schwab and others, 2013). The submerged Pleistocene glacial outwash lobe identified by Schwab and others (2014a) forms a subsurface topographic high in this area and corresponds spatially with the seaward bulge in the coastline along Fire Island (fig. 14). It is likely that erosion of the underlying outwash deposit in inter-ridge troughs supplies sediment contributing to the positive sediment budget in the central area. In the eastern zone, shoreface-attached sand ridges are absent, and the R0 horizon below T2 sediment truncates underlying Pleistocene outwash deposits (Schwab and others, 2013; fig. 9). T2 sediment is usually thin in the eastern zone, except for the nearshore bar and an evolving ebb tidal deposit that formed seaward of the wilderness breach after Hurricane Sandy (Brownell and others, 2015; figs. 19 and 20). 
The maximum Holocene thickness $(\mathrm{T} 1+\mathrm{T} 2)$ in the western zone is well over $10 \mathrm{~m}$, as estimated by projecting R1 landward in figure 13. The lower T1 wedge of sediment that downlaps seaward and westward (fig. 14) suggests a spit/shoal style of deposition that appears related to the westward migration of Fire Island Inlet over the last 400 years (Leatherman, 1985; fig. 14). This western T1 deposit originates from the possible inlet structure previously discussed and shown on Chirp profile 52 in figure 12. In this scenario, the thickening of T1 sediment offshore of Ocean Beach, (fig. 18) above the R1 reflector (fig. 12), could represent fill within a paleo-inlet, similar in orientation to the present Fire Island Inlet, which trends east-west. The paleo-inlet would have originally been on the back side of a prograding spit, as suggested by the $\mathrm{R} 0+\mathrm{R} 1$ structure contours seaward of Ocean Beach (fig. 16). It is inferred that the T1 sediment volume is derived from this prograding spit and ebb-tidal delta (spit platform) deposition. The island subsequently transgressed landward, leaving a section of inlet fill beneath the upper shoreface. In contrast to the small-scale mounded and localized relief observed at the wilderness breach ebb-tidal deposit in the eastern zone, the T1 strata patterns are thin and wedge shaped, forming a prograding spit platform extending westward during inlet migration. The burial of T1 by T2 sediment suggests that reworked T1 sediment, or an additional sediment supply_presumably from the east, along with the migration of shoreface-attached sand ridges — buried these spit platform deposits. The modern shoreface-attached ridges are within the T2 section only, indicating that, at least for the near future, the T1 sediment volume does not play a role in coastal sediment budgets.

Within the central zone, the boundary between the underlying Pleistocene and Holocene is less clear, and the lower T1 section is undifferentiated or absent. This discontinuous stratigraphy alongshore (fig. 15) could further reflect a history of inlet opening, migration, and closing, resulting in partial preservation of these reworked sediments below the island and in areas now occupied by the nearshorebar system.

\section{Stratigraphic Age Control}

There is no subsurface control for direct assessment of sedimentary facies and age within the nearshore sediments described. However, nearby boreholes on Fire Island collected by Schubert (2010), which were focused on water table and lithofacie relationships, provide some comparative assessment for the thickness of Holocene deposits.

Schubert collected four core transects across the island at Kismet, Robbins Rest, Watch Hill, and National Wilderness (within figures 16-19) that penetrated up to $30 \mathrm{~m}$ deep. Schubert described the Holocene deposits overlying the glacial outwash deposits as

"... fine sand and silt with beds of medium to coarse sand and layers of clay .... These deposits presumably include estuarine mud, relict seagrass beds, and peat deposits interbedded with flood-tidal-shoal, inlet-fill, and overwash deposits. This sequence of fine- to coarse-grained deposits likely resulted from landward barrier-island migration and a gradually rising sea level and is hereafter collectively referred to as lagoonal deposits" (Shubert 2010).

Most cores penetrated the Holocene section and recorded glacial outwash facies and an associated glacial aquifer. The thicknesses of Schubert's Holocene deposits agree well with the thicknesses of Holocene deposits identified in this study. Below western Fire Island, the nearshore thickness of Kismet and Robbins Rest Holocene deposits were 10-11 m compared with the projected total thickness of Holocene (T1+T2) deposits, which are estimated to be on the order of 10-14 $\mathrm{m}$ at $500 \mathrm{~m}$ away from 
the Schubert cores (figs. 12 and 13). At the Watch Hill core transect (central area), the Holocene section measured about $4 \mathrm{~m}$ thick, while the National Wilderness Holocene section (the eastern limit of the study) was about $3 \mathrm{~m}$ thick, comparing well with the nearshore Holocene thicknesses for the central and eastern zones as 3-5 m. The eastward thinning of the Holocene section below the island coincides with the overall thinning of the nearshore Holocene sediment toward the east (fig. 18).

Some insight on the relative age of $\mathrm{T} 2$ can be inferred from the stratigraphic relationships tied to the westward progradation of Fire Island in the past few hundred years. Because the lower T1 section in the western zone reflects deposition during inlet migration, the overlying T2 could represent a section reworked over the past few decades. Sediment above the base-of-bar reflector, within the T2 section, is presumed to be reworked on short interannual to decadal time scales. However, the chronographic significance of the base-of-bar reflector is not known; it could reflect infrequent major storms, and it might not be synchronous across the study area. Seaward of the bar and base-of-bar reflector, the T2 section merges with the shoreface-attached sand ridges, which are actively migrating (Schwab and others, 2014a) and respond to processes operating over decadal or longer time scales. Therefore, the T2 section represents a variable-age deposit that reflects processes operating on shorter time intervals nearshore (annual) and longer term processes offshore that form or maintain the sand ridges (decadal or longer). The exchange of sediment across the shoreface is likely to include some input of sediment to the nearshore bar system from the sand ridges as suggested by Schwab and others (2013) and could include sediment bypassing or erosion where the base-of-bar reflector outcrops at the seafloor.

\section{Summary}

This study maps the thickness of shoreface sediment at Fire Island, N.Y., to fill the nearshore data gap between the shoreline and inner shelf. This gap existed because shoaling waves and surf make the area difficult for boats to access. Provided with this report are two map products, the full Holocene isopach — which is compatible with previous inner shelf Holocene maps (Schwab and others, 2013, 2014a) - and the T2 isopach map (fig. 19). The T2 section is interpreted as representing the volume of sediment subject to erosion and reworking by storms and interannual to decadal sediment transport processes that contribute to shoreface rebuilding during fair-weather conditions. The thicknesses of shoreface-attached sand ridges on the inner shelf are also contained in this section. Across the submerged shoreface, the time scale for reworking processes modifying the T2 section is inferred to transition from short-term nearshore (interannual) to longer term offshore (decadal). Acquisition of sediment cores is needed to better understand the chronology of these sedimentary units.

The stratigraphic architecture of the nearshore is consistent with previous assessments of coastline variability. The thinner sediment inventory in the eastern zone of this study is correlated with coastal erosion. Accretional or stable behavior of central and western Fire Island is correlated with shoreface-attached ridges that are integrated within the T2 sequence. The T2 sediment section thus serves as the active sand reservoir for assessing sediment availability in relation to beach recovery and near-term vulnerability to future storms and sea-level rise. 


\section{Selected References}

Blake, E.S., Kimberlain, T.B., Berg, R.J., Cangialosi, J.P., and Beven, J.L., II., 2013, Tropical Cyclone Report-Hurricane Sandy (AL182012): Miami, Fla., National Hurricane Center, National Oceanic and Atmospheric Administration, Report AL182012, 157 p., accessed January 6, 2017, at http://www.nhc.noaa.gov/data/tcr/AL182012_Sandy.pdf.

Brownell, A.T., Hapke, C.J., Spore, N.J., and McNinch, J.E., 2015, Bathymetry of the Wilderness Breach at Fire Island, New York, June 2013: U.S. Geological Survey Data Series 914, accessed January 6, 2017, at https://doi.org/10.3133/ds914.

Denny, J.F., Danforth, W.W., Couch, S., and Schwab, W.C., 2015a, Swath bathymetry collected offshore of Fire Island and western Long Island, New York in 2014, U.S. Geological Survey Field Activity 2014-072-FA: U.S. Geological Survey data release, accessed January 6, 2017, at https://doi.org/10.5066/F7C827BX.

Denny, J.F., Schwab, W.C., Baldwin, W.E., Moore, E., and Bergeron, E., 2015b, High-resolution geophysical data collected offshore of Fire Island, New York in 2011, U.S. Geological Survey Field Activity 2011-005-FA: U.S. Geological Survey data release, accessed January 6, 2017, at https://doi.org/10.5066/F75X2704.

Hallermeier, R.J., 1981, A profile zonation for seasonal sand beaches from wave climate: Coastal Engineering, v. 4, p. 253-277, accessed January 6, 2017, at https://doi.org/10.1016/0378-3839(80)90022-8.

Hapke, C.J., Brenner, Owen, Hehre, Rachel, and Reynolds, B.J., 2013, Coastal change from Hurricane Sandy and the 2012-13 winter storm season-Fire Island, New York: U.S. Geological Survey Open-File Report 2013-1231, 37 p., accessed August 24, 2016, at https://pubs.usgs.gov/of/2013/1231/.

Hapke, C.J., Lentz, E.E., Gayes, P.T., McCoy, C.A., Hehre, Rachel, Schwab, W.C., and Williams, S.J., 2010, A review of sediment budget imbalances along Fire Island, New York - Can nearshore geologic framework and patterns of shoreline change explain the deficit?: Journal of Coastal Research, v. 26, no. 3, p. 510-522, accessed August 24, 2016, at https://doi.org/10.2112/08-1140.1.

Hapke, C.J., Plant, N.G., Henderson, R.E., Schwab, W.C., and Nelson, T.R., 2016, Decoupling processes and scales of shoreline morphodynamics: Marine Geology, v. 381, p. 42-53, accessed January 6, 2017, at https://doi.org/10.1016/j.margeo.2016.08.008.

Kana, T.W., 1995, A mesoscale sediment budget for Long Island, New York: Marine Geology, v. 126, nos. 1-4, p. 87-110, accessed August 24, 2016, at https://doi.org/10.1016/0025-3227(95)00067-9.

Kana, T.W., Rosati, J.D., and Traynum, S.B., 2011, Lack of evidence for onshore sediment transport from deep water at decadal time scales: Fire Island, New York. Journal of Coastal Research, v. 59 2011, p. 61-75, accessed January 6, 2017, at https://doi.org/10.2112/SI59-007.1

Kratzmann, M.G. and Hapke, C.J., 2012, Quantifying anthropogenically driven morphologic changes on a barrier island-Fire Island National Seashore, New York: Journal of Coastal Research, v. 28, no. 1, p. 76-88, accessed January 6, 2017, at https://doi.org/10.2112/JCOASTRES-D-10-00012.1.

Leatherman, S.P.,1985, Geomorphic and stratigraphic analysis of Fire Island, New York: Marine Geology, v. 63, nos. 1-4, p.173-195, accessed January 6, 2017, at https://doi.org/10.1016/0025-3227(85)90083-0

Lentz, E.E., and Hapke, C.J., 2011, Geologic framework influences on the geomorphology of an anthropogenically modified barrier island-Assessment of dune/beach changes at Fire Island, New York: Geomorphology, v. 126, n. 1-2, p. 82-96, accessed January 6, 2017, at https://doi.org/10.1016/j.geomorph.2010.10.032 
Lentz, E.E., Hapke, C.J., Stockdon, H.F., and Hehre, R.E., 2013, Improving understanding of near-term barrier island evolution through multi-decadal assessment of morphologic change: Marine Geology, v. 337, p. 125-139, accessed August 24, 2016, at https://doi.org/10.1016/j.margeo.2013.02.004.

Miselis, J.L., and McNinch, J.E., 2006, Calculating shoreline erosion potential using nearshore stratigraphy and sediment volume - Outer Banks, North Carolina: Journal of Geophysical Research, v. 111, no. F2, F02019, accessed August 24, 2016, at https://doi.org/10.1029/2005JF000389.

Nelson, T.R. and Hapke, C.J., 2015, Shoreface Response and Recovery to Hurricane Sandy, in Proceedings of the Coastal Sediments 2015 (eds. Wang, P., Rosati, J.D., and Cheng, J.), p. 14, accessed January 6, 2017, at https://doi.org/10.1142/9789814689977_0012

Nelson, T.R., Miselis, J.L., Hapke, C.J., Wilson, K.E., Henderson, R.E., Brenner, O.T., Reynolds, B.J., and Hansen, M.E., 2016, Coastal bathymetry data collected in June 2014 from Fire Island, New York-The wilderness breach and shoreface: U.S. Geological Survey Data Series 1007, accessed January 6, 2017, at https://doi.org/10.3133/ds1007.

Saville, Thorndike, 1960, Sand transfer, beach control, and inlet improvements, Fire Island Inlet to Jones Beach, New York: Coastal Engineering Proceedings, no. 7, chap. 44, p. 785-807, accessed January 6, 2017, at https://journals.tdl.org/icce/index.php/icce/article/viewArticle/2203.

Schubert, C.E., 2010, Analysis of the Shallow Groundwater Flow System at Fire Island National Seashore, Suffolk County, New York: U.S. Geological Survey Scientific Investigations Report 2009-5259, 106 p., accessed January 6, 2017, at https://pubs.usgs.gov/sir/2009/5259.

Schubert, C.E., Busciolano, Ronald, Hearn, P.P., Jr., Rahav, A.N., Behrens, Riley, Finkelstein, Jason, Monti, Jack, Jr., and Simonson, A.E., 2015, Analysis of storm-tide impacts from Hurricane Sandy in New York: U.S. Geological Survey Scientific Investigations Report 2015-5036, 75 p., accessed January 6, 2017, at https://doi.org/10.3133/sir20155036.

Schwab, W.C., Baldwin, W.E., and Denny, J.F., 2016, Assessing the impact of Hurricanes Irene and Sandy on the morphology and modern sediment thickness on the inner continental shelf offshore of Fire Island, New York: U.S. Geological Survey Open-File Report 2015-1238, 15 p., accessed January 6, 2017, at https://doi.org/10.3133/ofr20151238.

Schwab, W.C., Baldwin, W.E., Denny, J.F., Hapke, C.J., Gayes, P.T., List, J.H., and Warner, J.C., 2014a, Modification of the Quaternary stratigraphic framework of the Inner-Continental shelf by Holocene marine transgression-An example offshore of Fire Island, New York: Marine Geology, v. 355, p. 346-360, accessed on August 24, 2016, at https://doi.org/10.1016/j.margeo.2014.06.011.

Schwab, W.C., Baldwin, W.E., Hapke, C.J., Lentz, E.E., Gayes, P.T., Denny, J.F., List, J.H., and Warner, J.C., 2013, Geologic evidence for onshore sediment transport from the Inner Continental ShelfFire Island, New York: Journal of Coastal Research, v. 29, no. 3, p. 526-544, accessed August 24, 2016 at https://doi.org/10.2112/JCOASTRES-D-12-00160.1.

Schwab, W.C., Denny, J.F., and Baldwin, W.E., 2014b, Maps showing bathymetry and modern sediment thickness on the inner continental shelf offshore of Fire Island, New York, pre-Hurricane Sandy: U.S. Geological Survey Open-File Report 2014-1203, accessed January 6, 2017, at https://doi.org/10.3133/ofr20141203.

Schwab, W.C., Thieler, E.R., Allen, J.R., Foster, D.S., Swift, A.B., and Denny J.F., 2000, Influence of inner-continental shelf geologic framework on the evolution and behavior of the barrier-island system between Fire Island Inlet and Shinnecock Inlet, Long Island, New York: Journal of Coastal Research, v. 16, no. 2, p. 408-422, accessed on August 24, 2016 at http://www.jstor.org/stable/4300050. 
Sopkin, K.L., Stockdon, H.F., Doran, K.S., Plant, N.G., Morgan, K.L.M., Guy, K.K., and Smith, K.E.L., 2014, Hurricane Sandy-Observations and Analysis of Coastal Change: U.S. Geological Survey OpenFile Report 2014-1088, 54 p., accessed October 24, 2016, at https://doi.org/10.3133/ofr20141088.

Stone, B.D. and Borns, H.W., Jr., 1986, Pleistocene glacial and interglacial stratigraphy of New England, Long Island, and adjacent Georges Bank and Gulf of Maine: Quaternary Science Reviews, v. 5, p. 39-52, accessed August 24, 2016, at https://doi.org/10.1016/0277-3791(86)90172-1.

Warner, J.C., List, J.H., Schwab, W.C., Voulgaris, George, Armstrong, Brandy, and Marshall, Nicole, 2014. Inner-shelf circulation and sediment dynamics on a series of shoreface-connected ridges offshore of Fire Island, NY: Ocean Dynamics, v. 64, no. 12, p. 1,767-1,781, accessed August 24, 2016, at https://doi.org/10.1007/s10236-014-0781-y.

Wilson, K.E., Adams, P.N., Hapke, C.J., Lentz, E.E., and Brenner, Owen, 2015, Application of Bayesian Networks to hindcast barrier island morphodynamics: Coastal Engineering, v. 102, p. 30-43, accessed January 6, 2017, at https://doi.org/10.1016/j.coastaleng.2015.04.006 


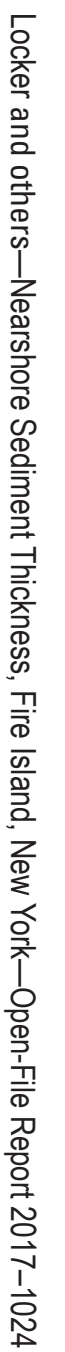

